\title{
Water Resources and Potential Hydrologic Effects of Oil-Shale Development in the Southeastern Uinta Basin, Utah and Colorado
}

\section{U.S. GEOLOGICAL SURVEY PROFESSIONAL PAPER 1307}

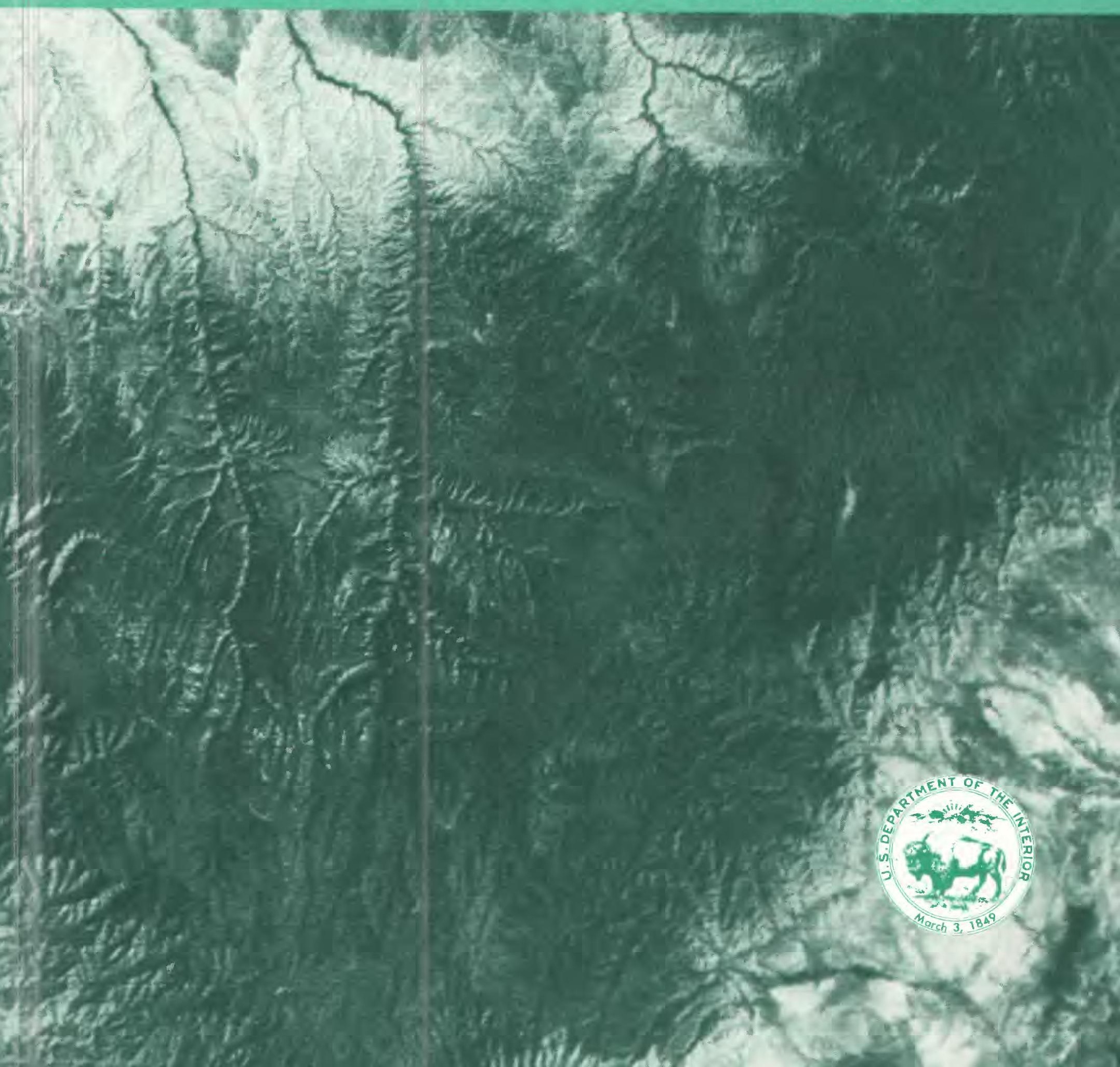



Water Resources and Potential Hydrologic Effects of Oil-Shale Development in the Southeastern Uinta Basin, Utah and Colorado

By K. L. LINDSKOV and B. A. KIMBALL

U.S. GEOLOGICAL SURVEY PROFESSIONAL PAPER 1307



$\overline{\text { UNITED STATES GOVERNMENT PRINTING OFFICE, WASHINGTON : } 1984}$ 


\title{
UNITED STATES DEPARTMENT OF THE INTERIOR \\ WILLIAM P. CLARK, Secretary
}

\section{GEOLOGICAL SURVEY}

\author{
Dallas L. Peck, Director
}

Library of Congress Cataloging in Publication Data

Lindskov, K. L.

Water resources and potential hydrologic effects of oil-shale development in the southeastern Uinta Basin, Utah and Colorado.

(Geological Survey professional paper; 1307)

Bibliography: $32 \mathrm{p}$.

1. Oil-shale industry-Environmental aspects-Uinta Basin (Utah and Colo.) 2. Watersupply-Uinta Basin (Utah and Colo.) 3. Hydrology-Uinta Basin (Utah and Colo.) I. Kimball, Briant A. II. Title. III. Series.

TD195.04L56 1984

$338.4^{\prime} 76654$

83-600313

For sale by the Branch of Distribution, U.S. Geological Survey, 604 South Pickett Street, Alexandria, VA 22304 


\section{CONTENTS}

Abstract

Introduction

Purpose and scope

Geographic, geologic, and hydrologic setting -

Previous investigations

The hydrologic system-

Major rivers

Intra area

Precipitation

Surface-water runoff

Ground water -

Evapotranspiration

Summary of intra-area water budget -.....................

Water requirements for an oil-shale industry

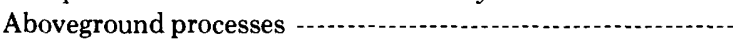

In situ processes

Total requirements

Selected sources of water supply for an oil-shale industry

White River -

Natural flow
Page

Selected sources of water supply for an oil-shale industryContinued

White River-Continued

Regulated flow

White River Dam -..................................... 22

Off-stream storage in Hells Hole Canyon -........... 23

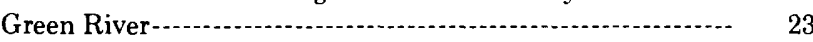

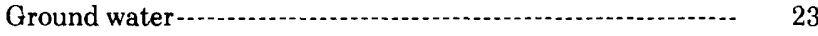

Potential impacts of an oil-shale industry on water resources ...- 24

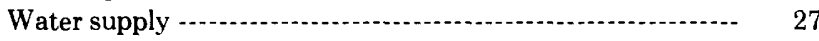

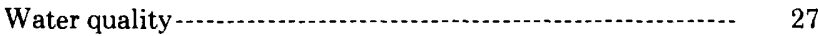

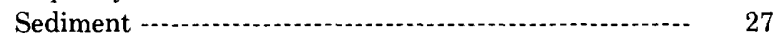

Potential effects of the White River Dam .......... 27

Potential effects of oil-shale processing facilities --- $\quad 27$

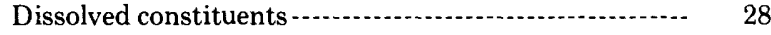

Dissolved solids -......................................... 28

Total organic carbon -.......................... 28

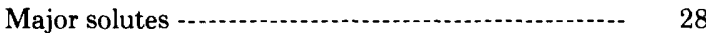

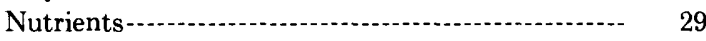

Trace elements -

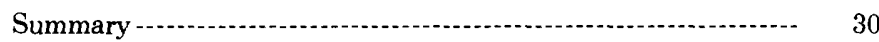

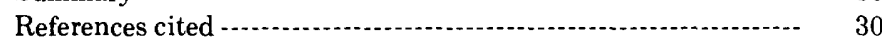

\section{ILLUSTRATIONS}

FiguRES 1-4. Maps showing:

1. Location of study area within the Upper Colorado River Basin

2. Geographic features

3. Land ownership

4. Lands for which Utah is seeking ownership-

5. Schematic stratigraphic section of the formations of early Tertiary age

6. Graph showing magnitude and frequency of annual precipitation at Bonanza, Utah

7. Graphs showing seasonal variations in precipitation at four representative sites, 1941-70

8. Map showing average annual runoff -.

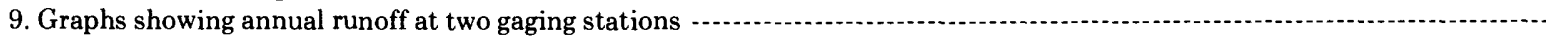

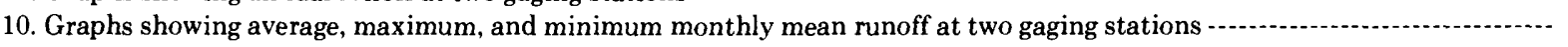

11-14. Maps showing:

11. General quality of surface water -

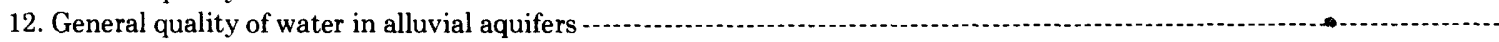

13. General quality of water in the bird's-nest aquifer in the Parachute Creek Member of the Green River Formation -.-...-

14. General quality of water in the Douglas Creek aquifer -

15. Graph showing annual precipitation and potential evapotranspiration at Fort Duchesne, Utah, 1943-75 -......................

16. Map showing proposed areas of oil-shale mining (1981)

17. Graph showing magnitude and frequency of annual low flows at station 09306500 , White River near Watson -..................

18. Graph of daily-duration hydrographs for indicated percentage of time flow at station 09306500 , White River near Watson, was equal to or greater than that shown

19. Map showing location of proposed projects that may be associated with an oil-shale industry -....................................

20. Map showing approximate areal extent used in determination of maximum annual yields from the consolidated-rock aquifers 


\section{TABLES}

$\begin{array}{ll}\text { TABLE } & \text { 1. Summary of water requirements for a 100,000-barrel-per-day oil-shale mine with retorting above ground -...............-... } \\ \text { 2. Summary of water requirements for a } 100,000 \text {-barrel-per-day oil-shale mine with retorting by the Occidental modified in situ }\end{array}$ process

3. Comparison of mean chemical composition of four retort waters with natural waters in the southeastern Uinta Basin

\section{CONVERSION FACTORS}

Most values in this report are given in inch-pound units. For those readers who may prefer to use metric units rather than inch-pound units, the conversion factors for the terms used in the report are listed below. The conversion factors are shown to four significant figures.

\begin{tabular}{lcl}
\multicolumn{1}{c}{ Multiply } & $\underline{\text { By }}$ & \\
Acre & 0.4047 & \multicolumn{1}{c}{ To obtain } \\
& 0.004047 & Square hectometer \\
Acre-foot & 0.001233 & Cubuare kilometer \\
& 1233 & Cubic meter \\
Acre-foot per square mile & 476.1 & Cubic meter per square kilometer \\
Acre-foot per year & 0.001233 & Cubic hectometer per year \\
Barrel & 0.1590 & Cubic meter \\
Barrel per day & 159.0 & Liter per day \\
Cubic foot per second & 0.02832 & Cubic meter per second \\
Foot & 0.3048 & Meter \\
Foot per mile & 0.1894 & Meter per kilometer \\
Gallon & 3.785 & Liter \\
Gallon per minute & 0.06309 & Liter per second \\
Inch & 25.40 & Millimeter \\
& 2.540 & Centimeter \\
Inch per hour & 25.40 & Millimeter per hour \\
Mile & 1.609 & Kilometer \\
Square mile & 2.590 & Square kilometer \\
Ton per acre per hour & 2.242 & Metric ton per square hectometer per hour \\
Ton per day & 0.9072 & Metric ton per day \\
\hline
\end{tabular}

Chemical concentration and water temperature are given only in metric units. Chemical concentration is given in milligrams per liter or micrograms per liter. Milligrams per liter is a unit expressing the solute per unit volume (liter) of water. One thousand micrograms per liter is equivalent to 1 milligram per liter. For concentrations less than 7,000 milligrams per liter, the numerical value is about the same as for concentrations in parts per million.

Water temperature is given in degrees Celsius $\left({ }^{\circ} \mathrm{C}\right)$, which can be converted to degrees Fahrenheit $\left({ }^{\circ} \mathbf{F}\right)$ by the following equation: ${ }^{\circ} \mathrm{F}=1.8\left({ }^{\circ} \mathrm{C}\right)+32$.

A barrel is equal to 42 gallons of oil. 


\title{
WATER RESOURCES AND POTENTIAL HYDROLOGIC EFFECTS OF OIL-SHALE DEVELOPMENT IN THE SOUTHEASTERN UINTA BASIN, UTAH AND COLORADO
}

\author{
By K. L. Lindskov and B. A. KimbalL
}

\begin{abstract}
ABSTRAC'T
Proposed oil-shale mining in northeastern Utah is expected to impact the water resources of a 3,000-square-mile area. This report summarizes a comprehensive hydrologic investigation of the area which resulted in 13 published reports. Hydrologic information obtained during 1974-80 was used to evaluate the availability of water and to evaluate potential impacts of an oil-shale industry on the water resources.

The study area is the southeastern part of the Uinta Basin, Utah and Colorado, where the hydrology is extremely variable. The normal annual precipitation averages 11 inches and varies with altitude. It ranges from less than 8 inches at altitudes below 5,000 feet along the White and Green Rivers to more than 20 inches where altitudes exceed 9,000 feet on the Roan Plateau.

The White and Green Rivers are large streams that flow through the area. They convey an average flow of 4.3 million acre-feet per year from outside drainage areas of about 34,000 square miles, which is more than 150 times as much flow as that originating within the area. Streams originating in areas where precipitation is less than 10 inches are ephemeral. Mean annual runoff from the study area is about 28,000 acre-feet and ranges from less than 0.1 to 1.6 inches, depending on the location. At any given site, runoff varies greatly from year to year and season to season. Potential evapotranspiration is large, exceeding precipitation in all years.
\end{abstract}

Three major aquifers occur in the area. They are alluvial deposits of small areal extent along the major stream valleys; the bird's-nest aquifer of the Parachute Creek Member of the Green River Formation, which is limited to the central part of the study area; and the Douglas Creek aquifer of the Douglas Creek Member of the Green River Formation, which underlies most of the area. Total recoverable water in storage in the three aquifers is about 18 million acre-feet. Yields of individual wells and interference between wells limit the maximum practical withdrawal to about 20,000 acre-feet per year.

An oil-shale industry in the southeastern Uinta Basin with a peak production of 400,000 barrels of oil per day would require a water supply of about 70,000 acre-feet per year. Sources of water supply considered for such an industry were: diversion from the natural flow of the White River, a proposed reservoir on the White River, diversion from the White River combined with proposed off-stream storage in Hells Hole Canyon, diversion from the Green River, and conjunctive use of ground and surface water.

The proposed reservoir on the White River would trap about 90 percent of the sediment moving in the river and in turn would release almost sediment-free water. Possible impacts are changes in channel gradient in the downstream 18 miles of the White River and changes in bank stability. In some parts of the area, annual sheet-erosion rates are as great as 2.2 acre-feet per square mile but sediment yield to the White River is less than might be expected because the runoff is small. If process water from retort operations or water used in the construction of surface facilities is discharged into a normally dry streambed, increased channel erosion and sediment in tributary streams could result in increased sediment loads in the White River. In addition, sediment yields from retorted-shale piles with minimum slopes could exceed 0.1 acrefoot per square mile during a common storm. Thus, without safeguards, the useful life of any proposed reservoir or holding pond could be decreased considerably.

Leachate water from retorted-shale piles has large concentrations of sodium and sulfate, and the chemical composition of retort waters differs considerably from that of the natural waters of the area. The retort waters contain a greater concentration of dissolved solids and more organic carbon and nutrients. Without proper disposal or impoundment of retort and leachate waters, the salinity of downstream waters in the Colorado River Basin would be increased.

\section{INTRODUCTION}

\section{PURPOSE AND SCOPE}

The dependence of the United States on imported petroleum supplies has focused attention on oil-shale deposits in the Upper Colorado River Basin in the western part of the country. Most of the Nation's high-grade deposits of oil shale are in the Green River Formation of Tertiary age in Colorado, Utah, and Wyoming (fig. 1). Large-scale mining and processing of the oil shale could produce oil that would be an alternative to help meet the Nation's energy needs. A large-scale oil-shale industry, however, would have considerable impact on the area's water resources.

This report summarizes the results of a comprehensive hydrologic investigation of a 3,000-square-mile area of the southeastern Uinta Basin, Utah and Colorado (fig. 2 ), an area containing extensive thick deposits of oil shale. Hydrologic information obtained during the study is used to evaluate the availability of water for an oilshale industry and to evaluate potential impacts of an oil-shale industry on the area's water resources. Information obtained during the investigation included data for ground water, streams, climate, channel migration, vegetation, and geology in relation to spring discharge. The data and interpretations were published in 13 reports, 


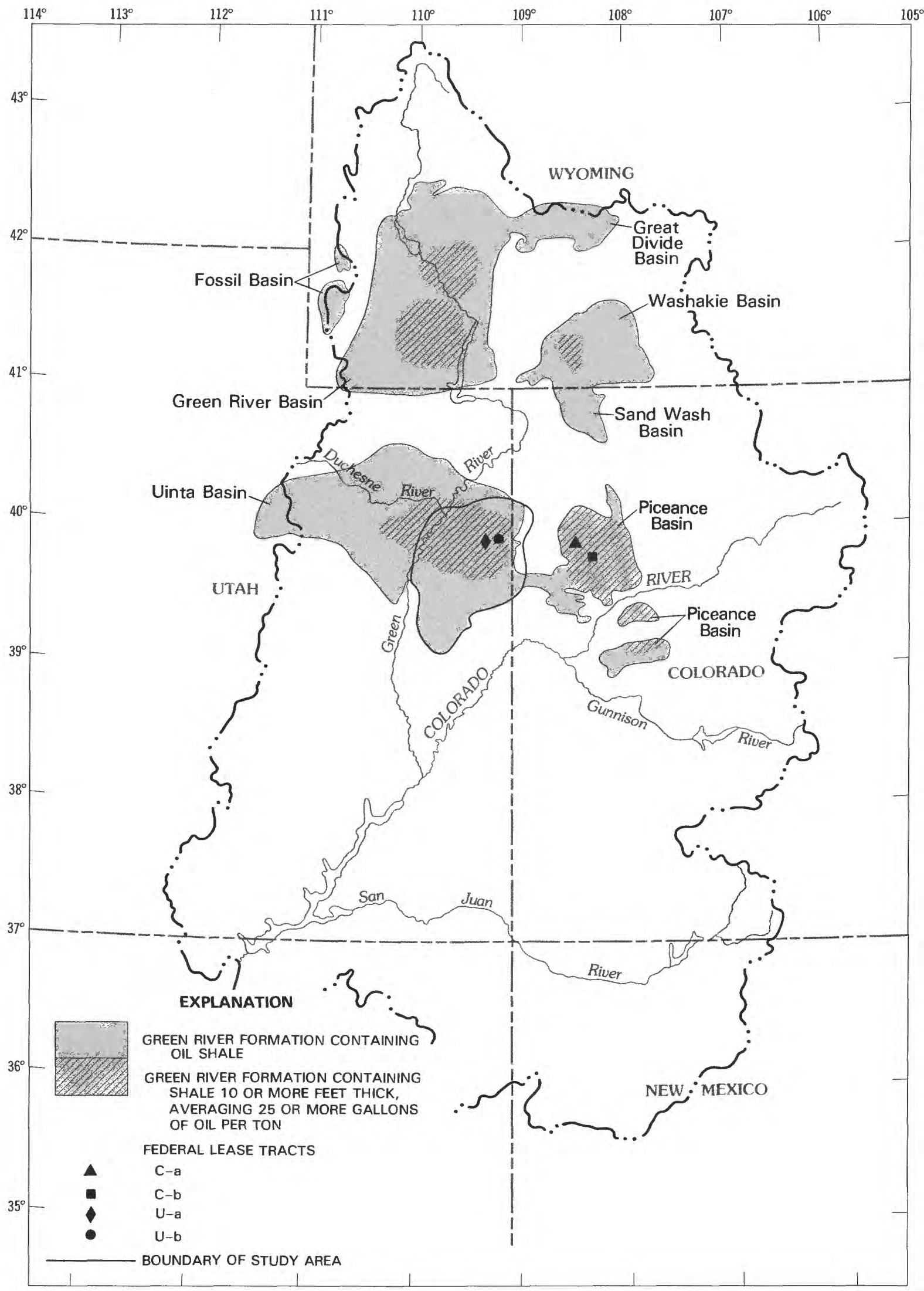

FIGURE 1.- - Location of study area within the Upper Colorado River Basin. Boundaries of structural basins within the region from U.S. Department of the Interior (1979, p. 17). 
INTRODUCTION
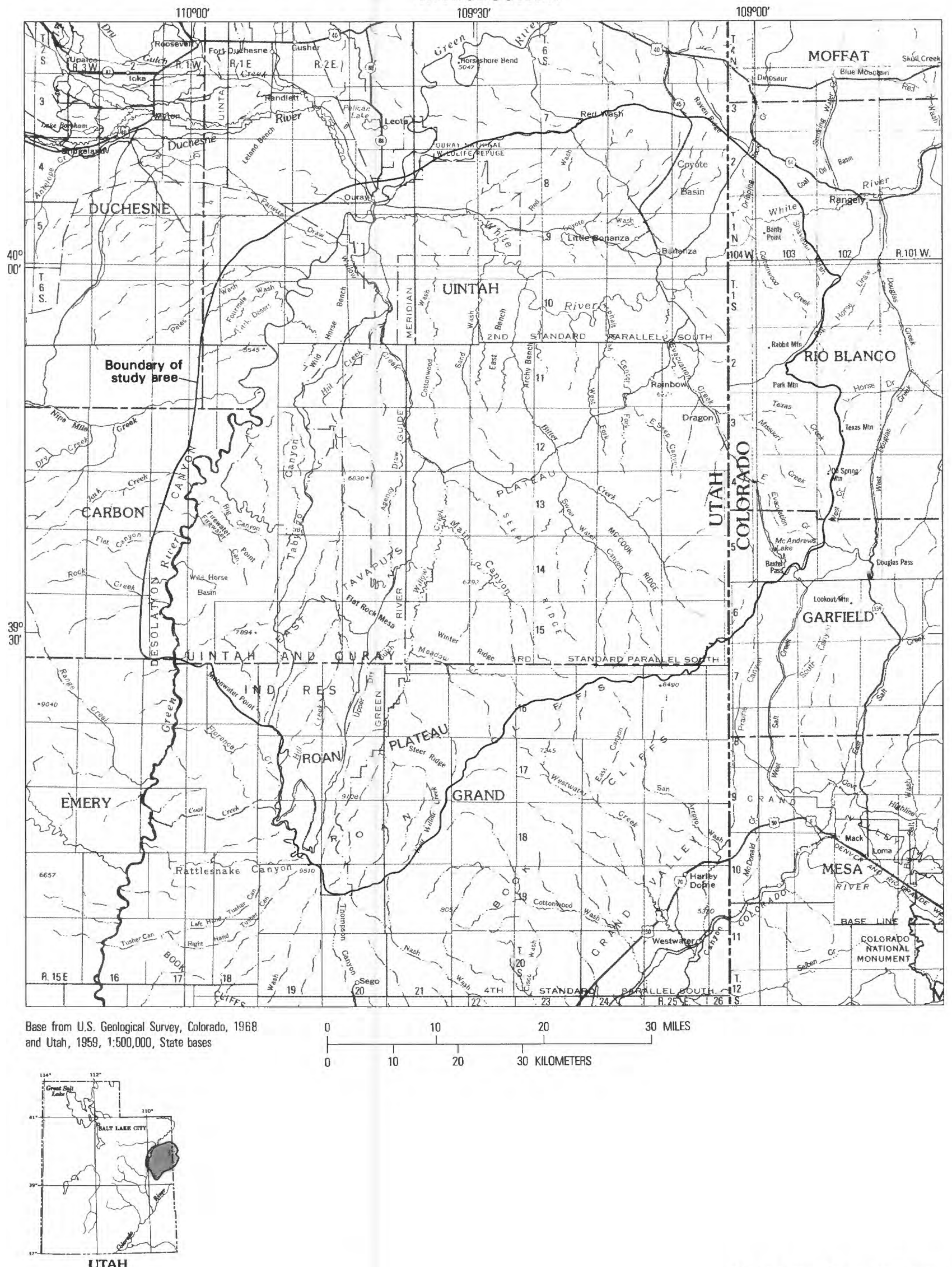

FIGURE 2.-Geographic features. 
which are identified by asterisks in the references cited at the end of this report.

The investigation began in October 1974, and from 1 to 6 years of stream, climate, and ground-water data were obtained at many sites. Included were: (1) Streams - 30 gaging stations for continuous records of flow and monthly-to-quarterly water-quality sampling, 12 of the gaging stations for biological sampling, 19 partial-record stations for monthly measurements of flow and waterquality sampling, 7 of the gaging stations for continuous records of sediment discharge, miscellaneous sediment data at other stations, and 7 of the gaging stations for continuous records of specific conductance and water temperature; (2) climate -21 sites for monthly and annual precipitation totals, 13 sites for precipitation intensity, 27 sites for snow depth, 3 snow courses, 7 sites for air temperature, 2 sites for relative humidity, and 1 site for pan evaporation; and (3) ground water -6 sites for monthly and 39 sites for quarterly measurements of water levels, discharge, water temperature, and specific conductance of water; 59 sites for annual water-quality sampling; and 40 sites for measuring soil-moisture content. In addition, there were 32 hillslope transects for measurement of erosion and 6 channel cross sections for measurement of scour and fill. Six test holes were completed in the consolidated rocks, with depths ranging from 800 to 3,000 feet.

Data obtained during October 1974 to September 1978 were published in Conroy and Fields (1977) and Conroy (1979, 1980). Data obtained since September 1978 appear in annual releases entitled "Water Resources Data for Utah" (U.S. Geological Survey, 1980-82). Results of drilling and testing are given in Holmes (1980); and results of all interpretive work appear in Butler and England (1979), Holmes (1979), Holmes and Kimball (1983), Jurado and Fields (1978), Kimball (1981), Lindskov and Kimball (1982), Naten and Fuller (1981), Seiler and Tooley (1982), and Waltemeyer (1982).

\section{GEOGRAPHIC, GEOLOGIC, AND HYDROLOGIC SETTING}

The study area is about 3,000 square miles in the southeastern Uinta Basin, Utah and Colorado (fig. 2). Included are areas that drain to the reach of the White River between a point about 15 miles downstream of Rangely, Colo., to its confluence with the Green River near Ouray, Utah. Also included are most areas draining directly to the Green River from a point near Ouray downstream through Desolation Canyon. All drainage is ultimately to the Green River, which is the largest tributary of the Colorado River.
About 56 percent of the land in the study area is owned or administered by the Federal Government, 24 percent is in Indian trust, about 10 percent is State owned, and less than 10 percent is privately owned (fig. $3)$. Utah is seeking ownership of an additional 240 sections in the area (fig. 4) to offset lands (school sections) throughout the State that were originally designated for State ownership but not yet transferred from Federal ownership. Ownership of minerals commonly is different from ownership of the surface rights, but there is no attempt to portray mineral ownership in figure 3.

The study area is in the Colorado Plateaus physiographic province (Fenneman, 1946). Most of the larger streams originate on the Roan Plateau at altitudes greater than 8,000 feet above sea level ${ }^{1}$ and flow northward where they join with the White and Green Rivers at altitudes less than 5,000 feet. The streams originating in the study area are called intra-area streams in this report. Evacuation, Bitter, Hill, and Willow Creeks and Coyote Wash are examples of the major intra-area streams. Much of the variation in annual precipitation and resulting runoff in the study area are explained by variation in altitudes (Waltemeyer, 1982, p. 17, 18, fig. 8; Lindskov and Kimball, 1982, p. 41, fig. 12). Intra-area streamflow typically is perennial in the higher altitudes of the Roan Plateau, where annual precipitation may exceed 20 inches. As these streams flow through deeply incised canyons they become intermittent and ultimately ephemeral as they cross areas receiving less than 10 inches of precipitation annually.

About 52 percent of the study area drains to the White River, and the remaining 48 percent drains directly to the Green River. The long-term mean flow of the White River at the Colorado-Utah State line is about 700 cubic feet per second. The intra-area streams contribute only about 7 cubic feet per second to the White River, which is only 1 percent of the mean flow of the river and generally is less than evapotranspiration losses along the valley alluvium. The White River has no net gain in flow as it meanders between the State line and its confluence with the Green River near Ouray. The combined flow of the White, Duchesne, and Green Rivers near Ouray (draining about 34,000 square miles) averages about 5,900 cubic feet per second (4.3 million acre-feet per year) (Lindskov and Kimball, 1982, p. 32).

The chemical quality of the water in the southeastern Uinta Basin is strongly influenced by geology. During the Eocene Epoch a large lake, named Lake Uinta by Bradley $(1930$, p. 88$)$, occupied much of the area in the Piceance and Uinta Basins. The lake varied greatly in size

\footnotetext{
IThe datum used in this report is the National Geodetic Vertical Datum of 1929 (NGVD of 1929), a geodetic datum derived from a general adjustment of the first-order level nets of both the United States and Canada, formerly called mean sea level. NGVD of 1929 is referred to as sea level in this report.
} 


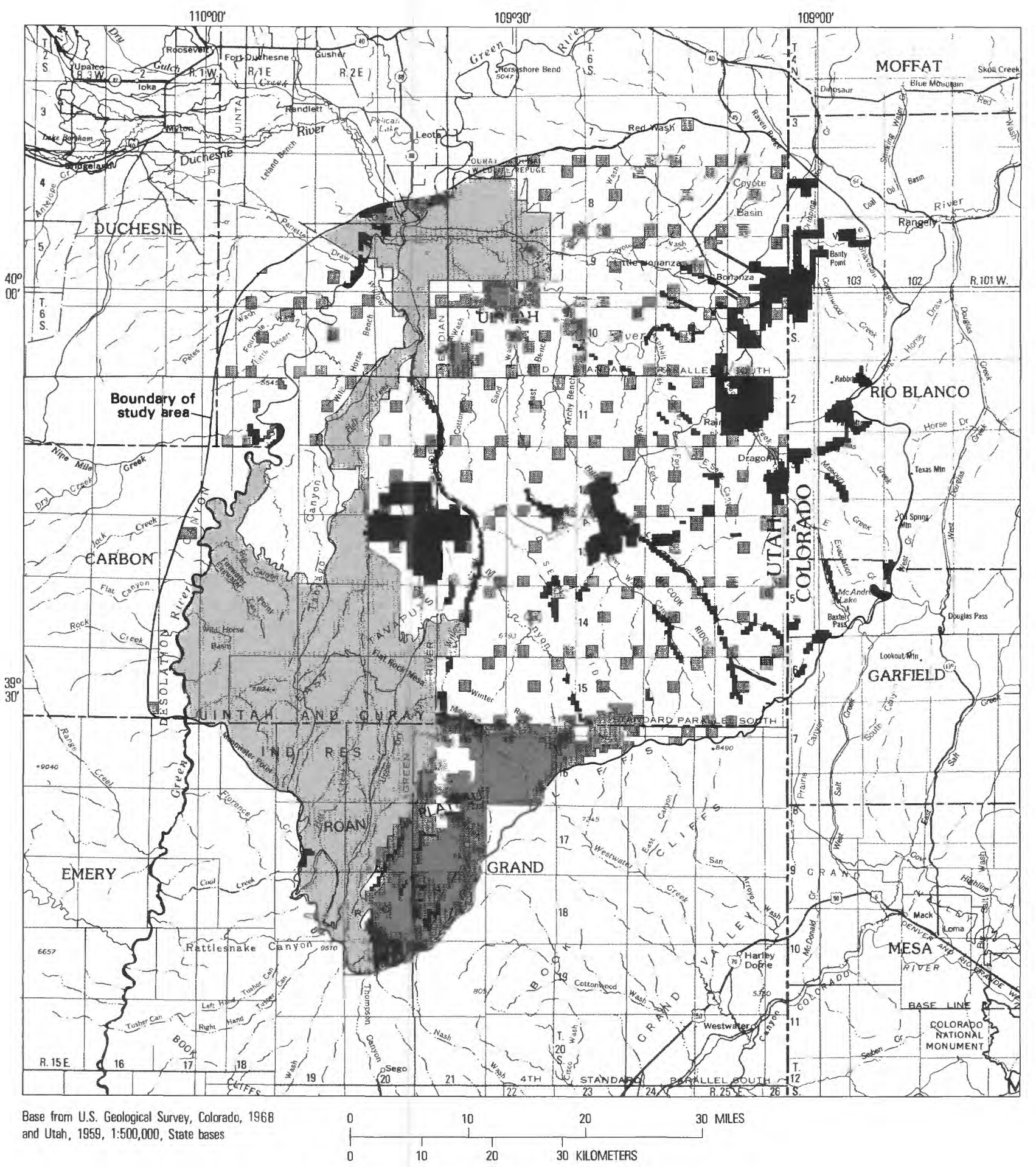

EXPLANATION

LAND OWNERSHIP STATUS

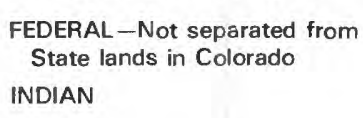

STATE-Included with Federal lands in Colorado

PRIVATE

FIGURE 3.-Land ownership. (Adapted from 1:500,000 scale land-status maps of Utah and Colorado prepared by the U.S. Bureau of Land Management, 1977, 1972.) Land status shown is generalized. Consult Land Office records for exact status of Public Domain. 


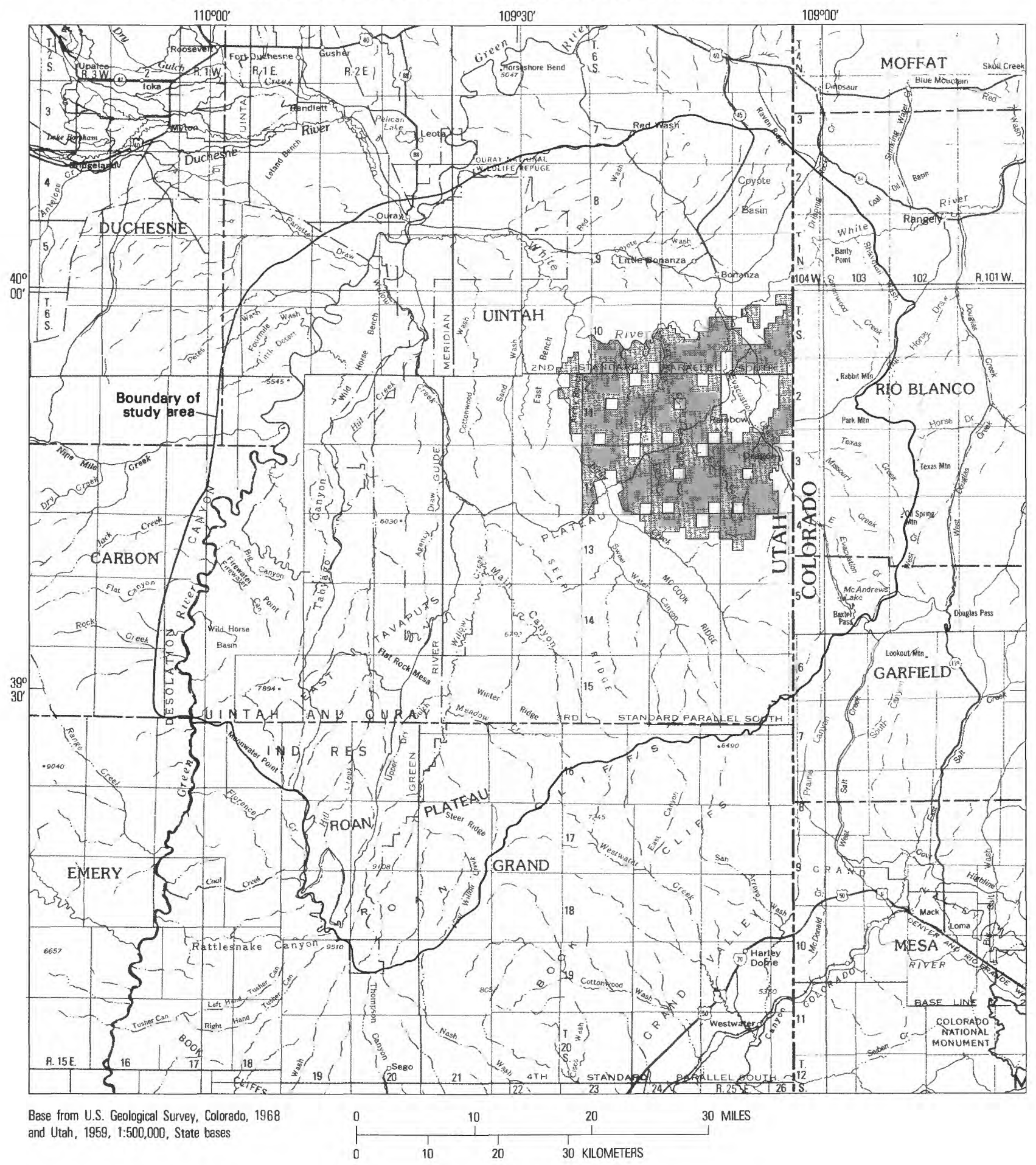

EXPLANATION

LANDS FOR WHICH UTAH IS

SEEKING OWNERSHIP

FIGURE 4.-Lands for which Utah is seeking ownership. (Adapted from a map provided by Gale Prince of the Utah State Lands Division in 1979.) 
and salinity, and the sediments deposited in the lake were consolidated to form rocks that are known as the Green River Formation. Intertonguing with the lacustrine sediments of the Green River Formation are the overlying Uinta Formation and the underlying Wasatch Formation, both of lacustrine origin and of Tertiary age. The relations between these formations (fig. 5) are described in detail by Cashion (1967 and 1973) and Cashion and Donnell (1974). Only those aspects that pertain to the effects on water resources are discussed here.

The Wasatch Formation underlies the Green River Formation and commonly intertongues with the Douglas Creek Member of the Green River Formation. The Wasatch is exposed around the margins of the area on the west, south, and east, and in the upper reaches of deep canyons. Cashion $(1967$, p. 6) has given the name Renegade Tongue to the intertonguing part of the Wasatch

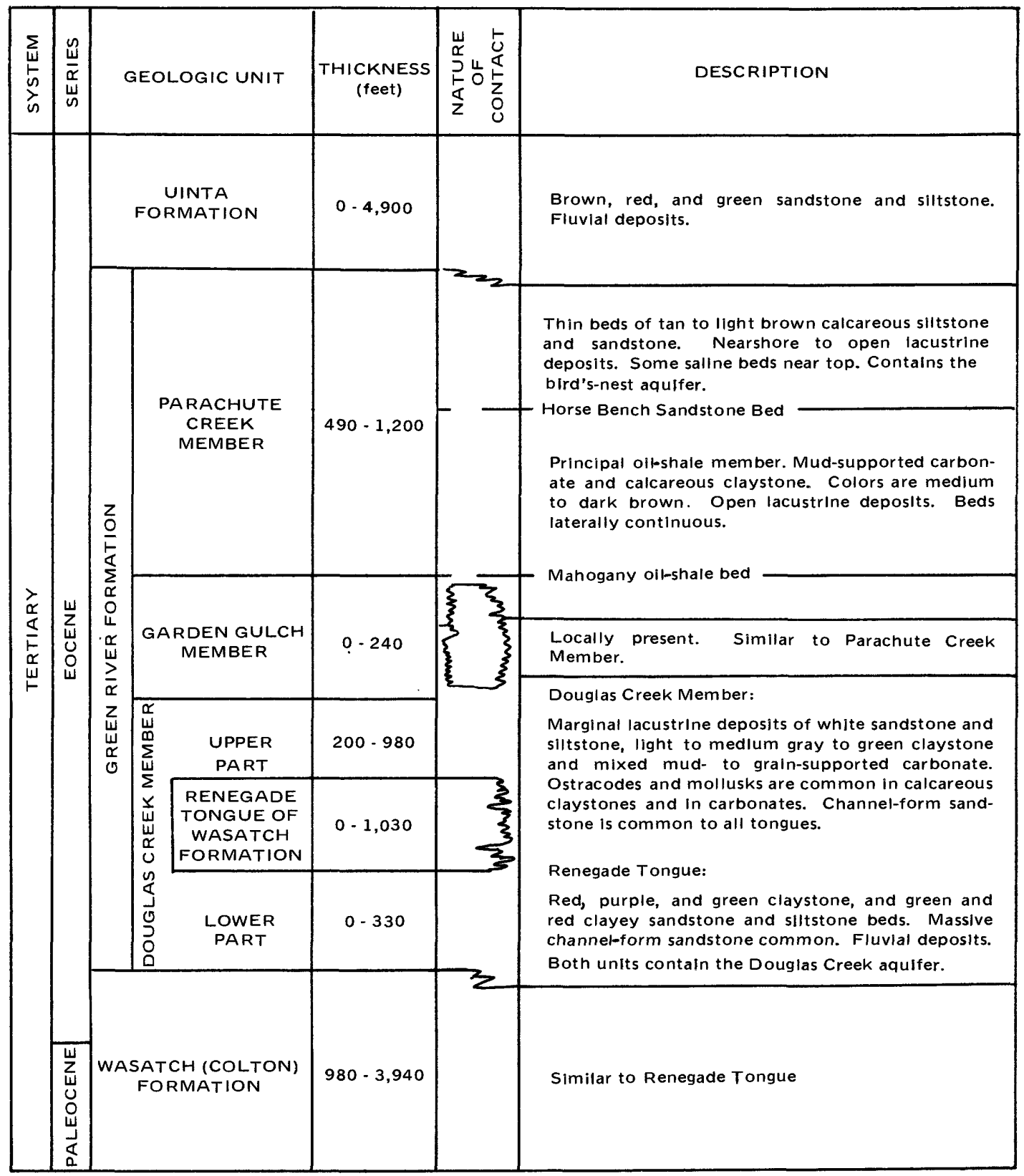

FIGURE 5.-Schematic stratigraphic section of the formations of early Tertiary age. Thickness data from Cashion (1967). 
Formation. The Renegade Tongue is part of the Douglas Creek aquifer as described by Holmes and Kimball (1983). Exposures of the Renegade Tongue contain claystone, siltstone, and massive channel sandstone.

The Green River Formation crops out in much of the study area, and the entire formation is exposed from south to north. The Douglas Creek Member is the principal unit cropping out in the Roan Cliffs as well as in the eastern one-half of the area. To the west, the Parachute Creek Member of the Green River Formation is exposed.

The Douglas Creek Member in the outcrop area consists of lacustrine and fluvial sandstone, siltstone, and claystone. Sandstone in this member increases to the south, and it commonly forms steep slopes and cliffs. The Garden Gulch Member of the Green River Formation locally is present in the northeast part of the area and is similar to the Parachute Creek Member. The Parachute Creek Member is mostly calcareous siltstone and claystone (marlstone). It contains oil-shale beds of commercial value, most notably the Mahogany oil-shale bed.

Weathering products from the Green River Formation are rich in clays. These are principally illite and mixedlayer illite-smectite clays, which are original constituents of the rocks and also products of weathering reactions. Alluvium in the canyons contains these clays along with variable-sized material derived from mechanical weathering.

A diverse mineralogy has been described for the Green River Formation (Milton and Eugster, 1959; Brobst and Tucker, 1973; Dyni, 1976). The minerals provide many possible sources of dissolved solids (including trace elements) in the natural waters of the area; however, most of the major solutes in streams are derived from only a few major minerals (Kimball, 1981, p. 9-13). The trace elements dissolved in the waters of the area generally are released by reactions between the water and the siltstone and claystone, particularly from the oil-shale beds. Desborough and others (1976) have described the abundance and mineralogical residence of many trace elements and major elements in the area.

The Uinta Formation, which conformably overlies the Green River Formation, consists of three "horizons" (Cashion, 1967, p. 19-21). Horizon A, which is the lowest, consists mostly of a sandstone and claystone sequence which crops out along the White River. Horizons $\mathrm{B}$ and $\mathrm{C}$ are exposed north of the White River. Horizon $\mathrm{C}$ weathers to a badlands topography and contains much expandable clay. The erosion of the badlands provides abundant suspended sediment to Coyote Wash, and in times of high flow in the wash, this sediment reaches the White River.

Movement of surface and ground water generally is northward from the areas along the Roan Plateau that receive the most precipitation. Streamflow diminishes significantly while flowing northward as evapotranspiration returns a large part of the water to the atmosphere. This process concentrates minerals that had been dissolved from the rocks over and through which the water had moved. Mining, retorting, and waste disposal of oil shale that contains saline minerals could possibly degrade the existing quality of the surface and ground water. In some areas, the surface and ground water are already saline (dissolved solids exceeding 10,000 milligrams per liter) and have appreciable concentrations of fluoride, boron, and sulfate. Thus, freshwater supplies need to be protected from degradation.

Trace metals, which are leached from the soils and rocks, become sorbed on the suspended sediment and bed material in the streams. The mining and processing of rock to obtain shale oil will increase the quantity of rock exposed for leaching. Without proper safeguards, traceelement transport and availability could increase beyond natural levels and pose a health hazard.

Vegetation is sparse because a large part of the area is arid. The barren land is severely eroded during summer thunderstorms and during years of above normal precipitation. A large part of the area is dissected hills and valleys, with some badlands, and source-area sediment yields can exceed 2 acre-feet per square mile per year. Erosion and transport of sediment at each mining site could result in a major water-quality problem unless topography, soils, and climate are adequately considered. Uncontrolled erosion rates resulting from active surface mining possibly could be 10 times greater (U.S. Department of the Interior, 1979, p. 34) than under natural conditions.

\section{PREVIOUS INVESTIGATIONS}

Woolley (1930) and Thomas (1952) described the hydrology of the Green River, including the reach that passes through the area of this investigation. Considerable hydrologic information for the general area is available in comprehensive studies of the water resources of the Upper Colorado River Basin by Iorns and others (1964 and 1965) and Price and Arnow (1974). Feltis (1966) compiled some information about the availability and chemical quality of ground water and briefly described the water-bearing properties of some of the geologic units in the Uinta Basin. Weir (1970) compiled considerable geohydrologic data obtained from an exploration well drilled in Uintah County. The U.S. Bureau of Reclamation (1974) identified specific alternative sources of water for use in oil-shale development on pro- 
totype areas, including tracts $\mathrm{Ua}$ and Ub near Bonanza, Utah (fig. 1).

Price and Miller (1975) reported the findings of a hydrologic reconnaissance of the southern Uinta Basin, including about 10,000 square miles that is south of the Strawberry, Duchesne, and White Rivers in Utah and Colorado. Their study included the area of investigation for this study, with the exception of the area draining to the White River from the north (fig. 2). That drainage was included in a hydrologic reconnaissance of the northern Uinta Basin reported on by Hood and Fields (1978).

In addition to the work mentioned above, oil companies have been involved in considerable data collection and analysis and premining studies, mostly in small areas. The White River Shale Project (VTN, Colorado, Inc., 1977) completed a report that presented the results of 2 years of premining data collection and analysis on Federal Lease Tracts Ua and Ub, each of which has an area of 8 square miles. The TOSCO Corp. and Geokinetics, Inc. are presently (1982) involved in premining data collection and analysis for small parts of the study area in the Sand Wash and Bitter Creek drainages and the Bitter and Willow Creek drainages, respectively. The hydrologic information obtained by the oil companies is valuable for evaluating impacts at the appropriate site and may be useful for estimating hydrologic characteristics at other sites.

\section{THE HYDROLOGIC SYSTEM}

\section{MAJOR RIVERS}

The Duchesne, Green and White Rivers convey water from a total of 34,000 square miles into the study area. The total average flow of these rivers is about 5,900 cubic feet per second or 4.3 million acre-feet per year. This is more than 150 times as much flow as the 39 cubic feet per second or 28,000 acre-feet per year that originates within the study area (Lindskov and Kimball, 1982, p. 32, 41). During periods of low flow in the Duchesne and White Rivers, the dissolved-solids concentration is almost 1,000 milligrams per liter, at which point it would become slightly saline. The quality of the water in the Green River is less affected by low flow because of the moderating effect of releases from the Flaming Gorge Reservoir upstream from the study area. The variability of the quantity and quality of the flows in the major rivers are reported in detail in Lindskov and Kimball (1982), and the flows of the Green and White Rivers are discussed later in "Selected sources of water supply for an oil-shale industry."

\section{INTRA AREA}

The quantity of water available in an area at any time is determined by the interactions of the various components of the hydrologic cycle. A water budget can be defined using the following equation:

(1) $I F+P=E T+O F_{ \pm}$storage changes

where

$I F$ is the inflow in streams and aquifers,

$P$ is the precipitation,

$E T$ is the evapotranspiration, and

$O F$ is the outflow in streams and aquifers.

About 4 million acre-feet of water per year enters and leaves the study area in the Duchesne, Green, and White Rivers. This water originates as precipitation that falls outside the study area, and it is largely isolated from the surface and ground water of the study area. Thus, only the runoff resulting from precipitation directly on the study area will be included in the water budget. Considering only those components that originate within the study area, equation (1) changes to:

(2) $\quad P=E T+R O+G W \pm$ storage changes

where $P$ and $E T$ are the same as in equation (1), $R O$ is the runoff in the intra-area streams resulting from precipitation on the study area, and $G W$ is the difference between ground-water inflow and outflow. Because there is no known ground-water inflow from outside the study area, only ground-water outflow is considered in equation (2). The quantity and quality of these components are discussed in the following sections and summarized in the section entitled "Summary of intra-area water budget."

\section{PRECIPITATION}

The normal annual precipitation that falls directly on the study area averages 11 inches (Waltemeyer, 1982, p. 18). Converted to an annual volume, this represents 1.8 million acre-feet, or an annual average of 195 million gallons for each square mile of area. However, the precipitation actually varies greatly from place to place and from time to time, mostly in response to changes in altitude. The normal annual precipitation ranges from less than 8 inches in areas where altitudes are below 5,000 feet to more than 20 inches in parts of the Roan Plateau where altitudes exceed 9,000 feet. The data in figure 6 indicate how total annual precipitation could vary during long periods at Bonanza, Utah, where the normal annual precipitation is 8.2 inches. During extremely dry years, precipitation could be as little as 4 inches and in extremely wet years as great as 15 inches.

As shown in figure 7 , the average precipitation at four representative sites in the study area is distributed fairly 


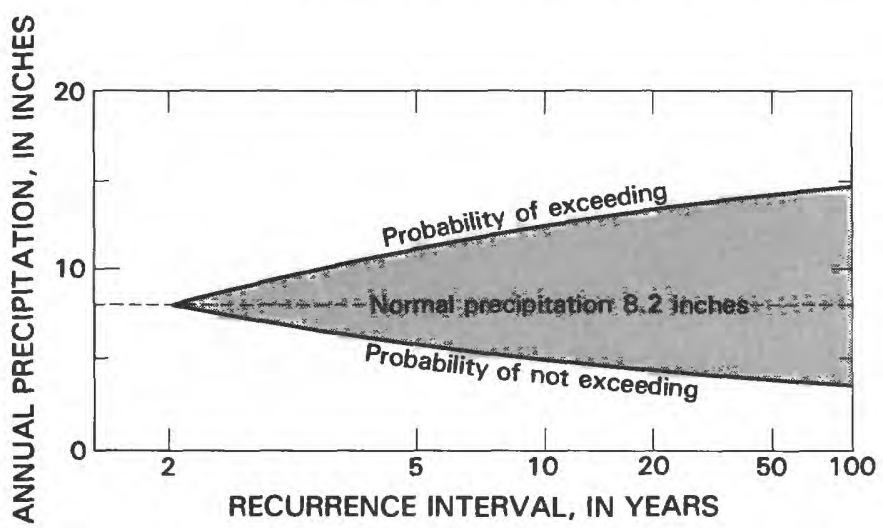

FIGURE 6.-Magnitude and frequency of annual precipitation at Bonanza, Utah. (Adapted from Waltemeyer, 1982, fig. 11.)

evenly throughout the year. Although the average monthly precipitation usually is slightly greater from April to October, in a given year any month can be either excessively wet or dry.

The information summarized above and that reported by Waltemeyer (1982) emphasize the variability in the quantity of precipitation that falls on the study area. These variations will become increasingly significant as we consider what happens to the precipitation once it reaches the land surface.

Precipitation that falls on the southeastern Uinta Basin contains few dissolved solids. Kimball (1981) describes how this water acquires dissolved solids as it interacts with soils and rocks in the area.

\section{SURFACE-WATER RUNOFF}

The runoff from the intra-area streams (streams originating in the study area) comes mostly from areas above 7,000 feet. The mean annual runoff is about 39 cubic feet per second, equivalent to 0.2 inch or 28,000 acre-feet per year (Lindskov and Kimball, 1982, p. 41). This is 1.6 percent of the 1.8 million acre-feet of precipitation that falls on the area during an average year. The largest unit runoff (average runoff per square mile) gaged was 1.6 inches for an 11.7-square-mile area in the headwaters of Bitter Creek. About two-thirds of the study area contributes an average of less than 0.1 inch of runoff (fig. 8).

The average runoff from the intra-area streams varies from one location to another and also varies seasonally and yearly at each location. The annual variation in runoff at two gaging stations, which together measure runoff from more than one-third of the study area, is shown in figure 9. Runoff in wet years can be five or more times greater than during dry years. The average monthly variations in runoff for these stations are shown in figure 10. A large part of the runoff occurs during March to June as snowmelt or during July and August when thunderstorm activity is great.

General changes in water quality in the streams in the study area expressed as dissolved-solids concentrations, are shown in figure 11. Even though concentrations are large, the contributions of the intra-area streams to the salinity of the major rivers is slight because of the small runoff from the intra-area streams. Runoff from thunderstorms in the intra-area streams, however, can contain dissolved-solids concentrations that are greater than normal because soluble salts in the streambeds are dissolved (Lindskov and Kimball, 1982, p. 109).

\section{GROUND WATER}

Three aquifers in the study area contain a large quantity of water (Holmes and Kimball, 1983). They are alluvial deposits of small areal extent along the major drainages; the bird's-nest aquifer of the Parachute Creek Member of the Green River Formation, which is limited to the central part of the study area; and the Douglas Creek aquifer of the Douglas Creek Member of the Green River Formation (includes the Renegade Tongue of the Wasatch Formation), which underlies most of the study area. There is no known ground-water inflow from outside the study area to any of these aquifers except for a small quantity in the alluvium in the White and Green Rivers. Bird's-nest aquifer corresponds to the bird's-nest zone as described by Cashion $(1967$, p. 17) because the outcrop of this informally named zone has the "appearance of a wall supporting many swallows' nests."

Within the study area, the recharge to the alluvium is about 32,000 acre-feet per year from infiltration of streamflow and inflow from the consolidated-rock aquifers (Holmes and Kimball, 1983, table 2). Discharge from the alluvium primarily is by evapotranspiration and also is estimated to be 32,000 acre-feet per year. The recoverable water in storage in the alluvium is about 200,000 

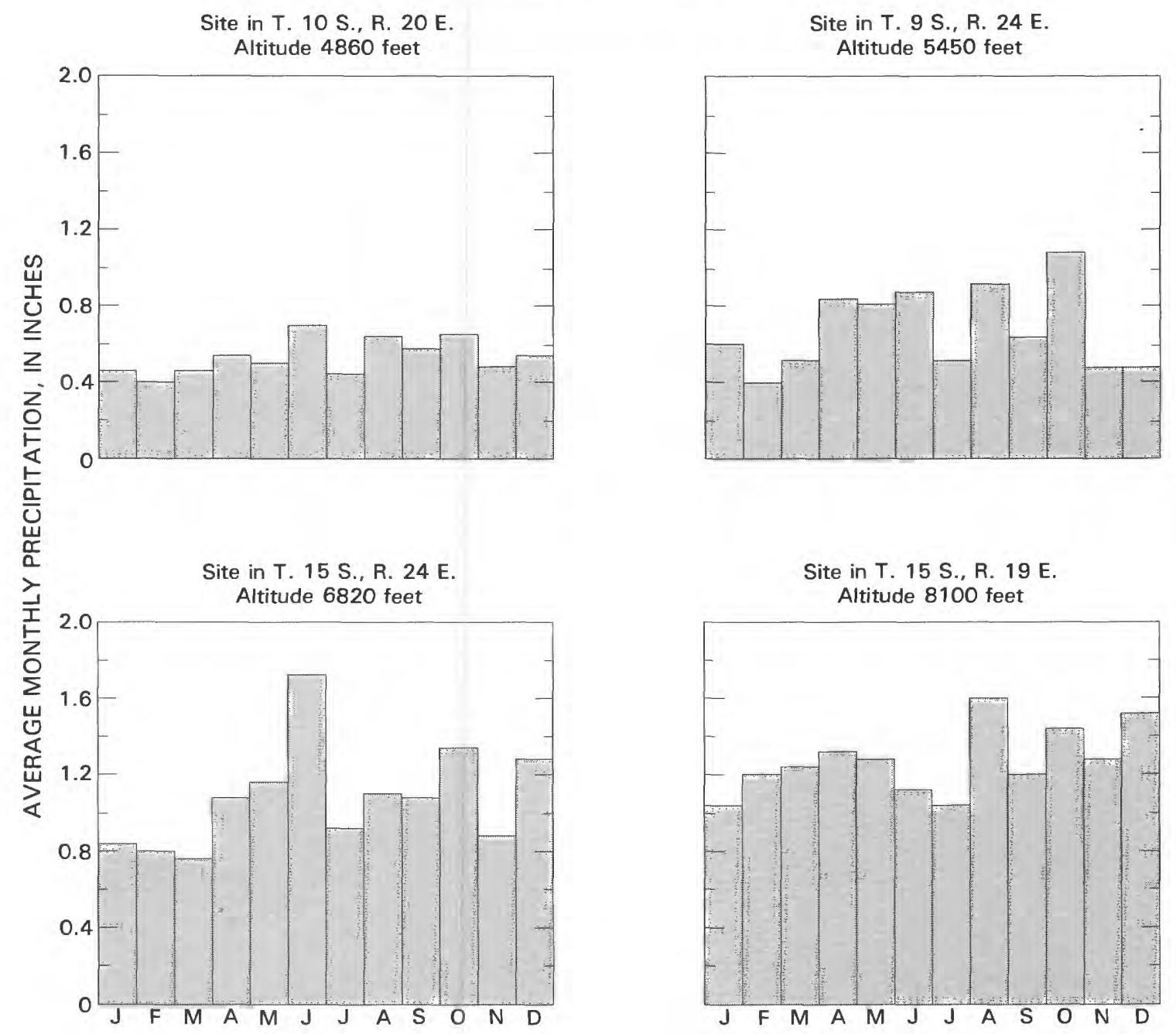

FIGURE 7.-Seasonal variations in precipitation at four representative sites, 1941-70. (Adapted from Waltemeyer, 1982, fig. 9.)

acre-feet (Holmes and Kimball, 1983, table 3).

The areal variation of water quality in the alluvium is shown in figure 12. In each of the intra-area drainages, the salinity of the water in the alluvium increases in a downstream direction, largely because of concentration by evapotranspiration. The water type generally changes downstream from a calcium magnesium sodium sulfate or bicarbonate type to a sodium sulfate type (Holmes and Kimball, 1983, fig. 6).
Within the study area, the recharge to the bird's-nest aquifer by infiltration of streamflow and downward leakage from the Uinta Formation is about 670 acre-feet per year. Discharge from the bird's-nest aquifer also is about 670 acre-feet per year, primarily by diffuse seepage to the White River and Bitter Creek. The recoverable water in storage in the bird's-nest aquifer is about 1.9 million acre-feet.

The areal variation of water quality in the bird's-nest 


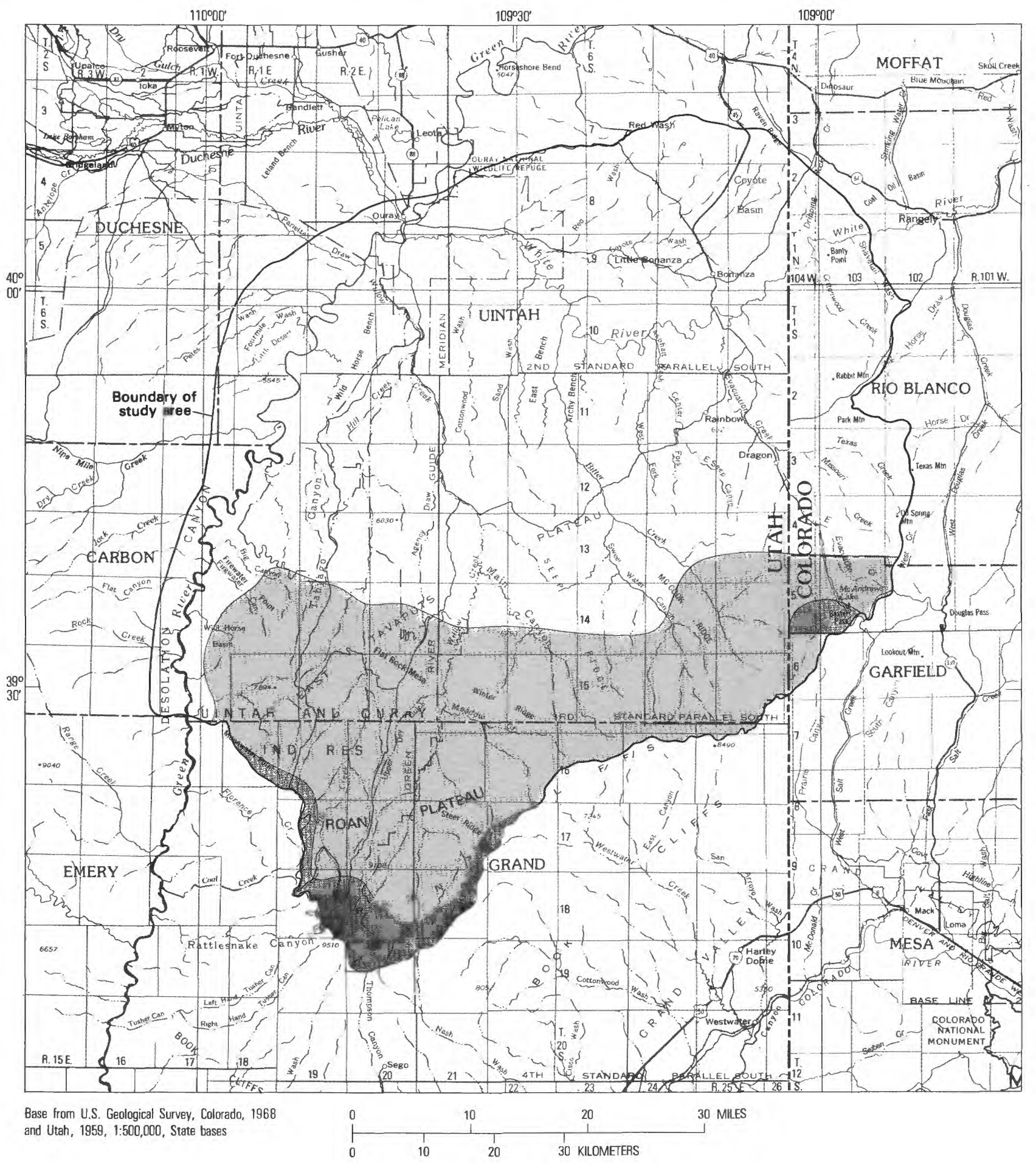

EXPLANATION

AVERAGE ANNUAL RUNOFF

LESS THAN $0.1 \mathrm{INCH}$

MORE THAN $1.0 \mathrm{INCH}$

0.1 TO $1.0 \mathrm{INCH}$

FiGURE 8.-Average annual runoff. (Adapted from Lindskov and Kimball, 1982, fig. 13.) 




FIGURE 9.-Annual runoff at two gaging stations.

aquifer is shown in figure 13. Most of the aquifer contains moderately saline water of the sodium bicarbonate or sulfate types (Holmes and Kimball, 1983, fig. 19). North of the White River, W. B. Cashion (U.S. Geological Survey, written commun., 1982) reports that samples obtained from test holes were briny, with dissolvedsolids concentrations of about 100,000 milligrams per liter. Thus, there appears to be a large increase of dissolved solids to the north. South of Bonanza, near the outcrop of the bird's-nest aquifer, recharge is primarily from Evacuation Creek (Holmes and Kimball, 1983). Near Asphalt Wash and Southam Canyon, recharge from the overlying Uinta Formation dilutes the water in the aquifer and reduction of sulfate causes the water to change to a sodium bicarbonate type.

Within the study area, the recharge to the Douglas Creek aquifer is by precipitation and infiltration of streamflow, which total about 20,000 acre-feet per year. Discharge from the Douglas Creek aquifer also is about 20,000 acre-feet per year, primarily through springs in the outcrop area. The recoverable water in storage in the Douglas Creek aquifer is about 16 million acre-feet.

The water in the Douglas Creek aquifer ranges from fresh to moderately saline, as shown in figure 14 . In the southern part of the study area, which is the recharge area for the aquifer, the dissolved-solids concentrations generally are less than 1,000 milligrams per liter. The water is mostly a mixed sodium magnesium sulfate bicarbonate type. As the water moves to the north, water-rock interactions increase the dissolved-solids concentration. Calcium and magnesium are quantitatively removed from solution by precipitation of carbonate minerals, and sulfate is reduced by anaerobic bacteria. Thus, the water becomes a sodium bicarbonate type (Holmes and Kim- 

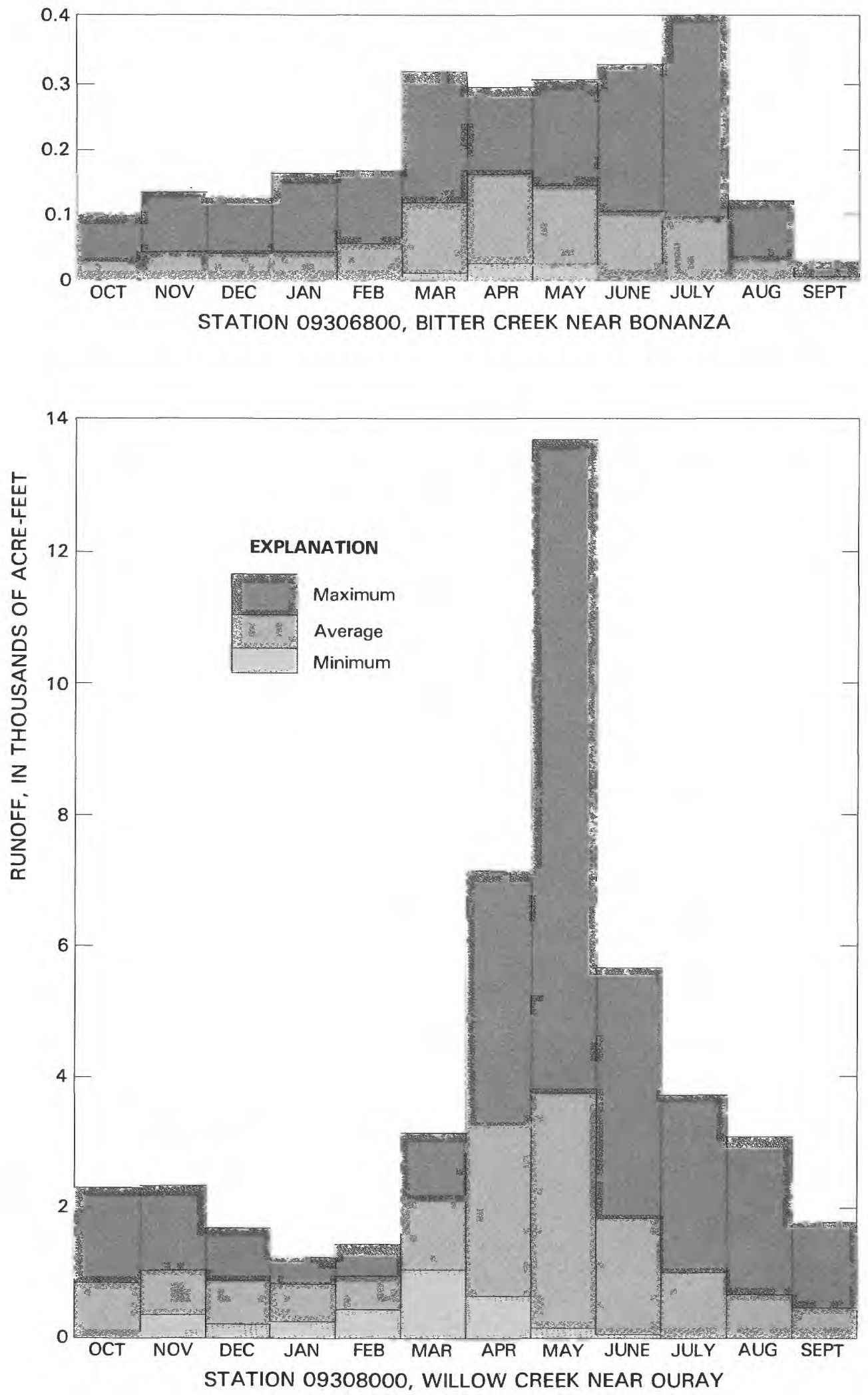

FIGURE 10.-Average, maximum, and minimum monthly mean runoff at two gaging stations.

ball, 1983). Goode and Feltis (1962, p. 17) have noted that the dissolved-solids concentration of water from the Red Wash field north of the study area ranges from about 5,000 to 26,000 milligrams per liter, and the water is a sodium chloride carbonate type. These wells produce water mostly from the Douglas Creek aquifer. 




MEAN DISSOLVED-SOLIDS CONCENTRATION, IN MILLIGRAMS PER LITER

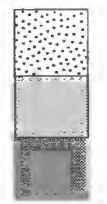

LESS THAN 1000, FRESH

1000-3000, SLIGHTLY SALINE

3000-10,000, MODERATELY SALINE

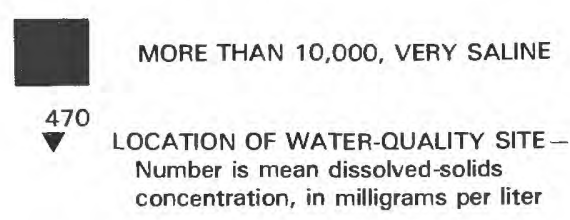

FIGURE 11.-General quality of surface water. 


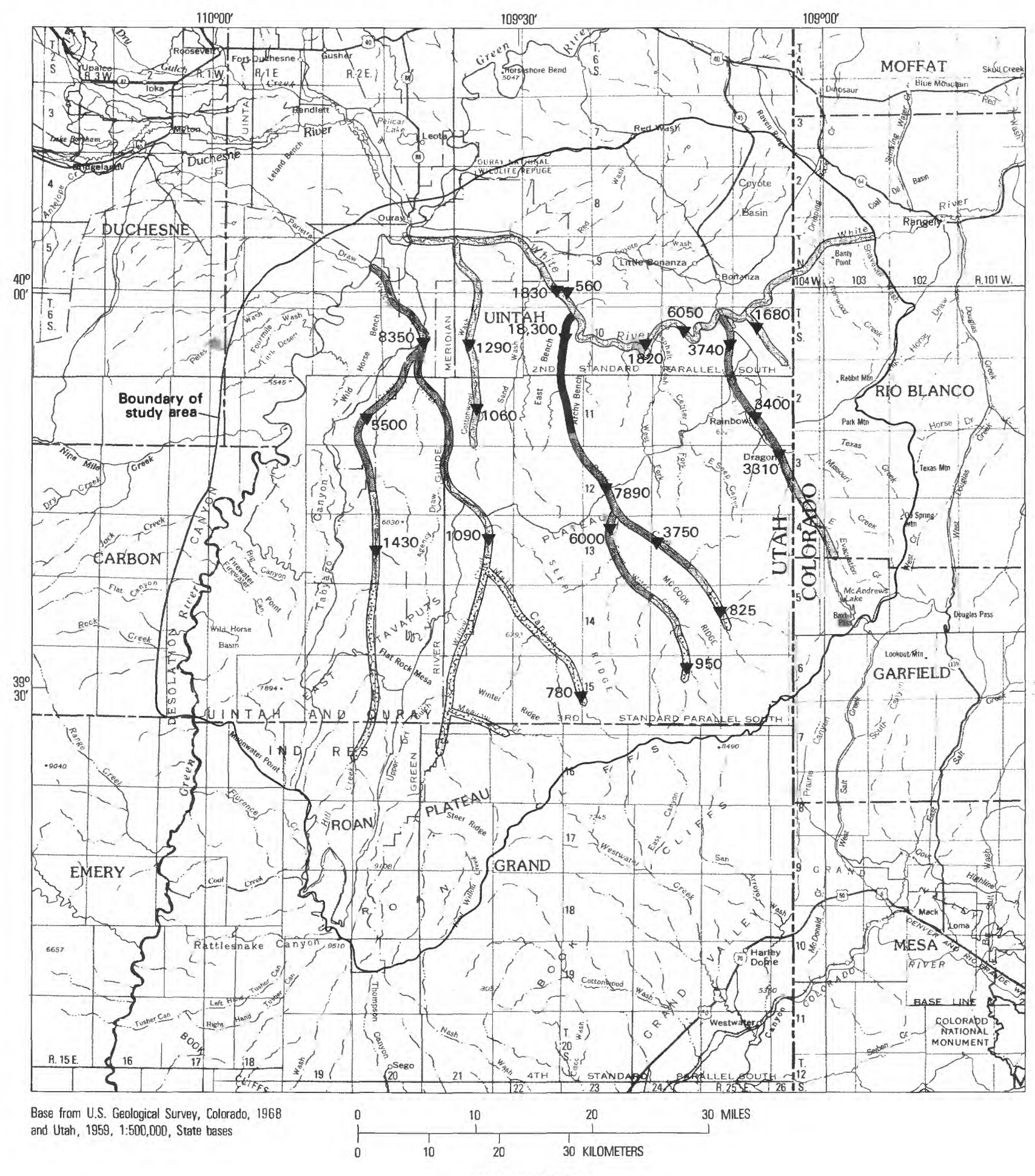

EXPLANATION

MEAN DISSOLVED-SOLIDS CONCENTRATION, IN MILLIGRAMS PER LITER

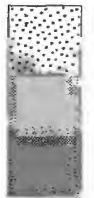

LESS THAN 1000, FRESH

1000-3000, SLIGHTLY SALINE

3000-10,000, MODERATELY SALINE

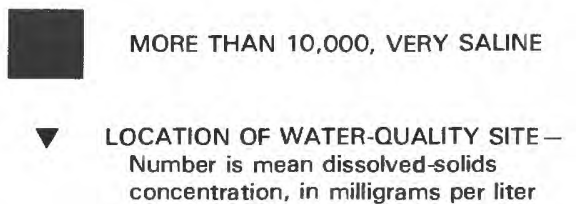

FIGURE 12.-General quality of water in alluvial aquifers. 


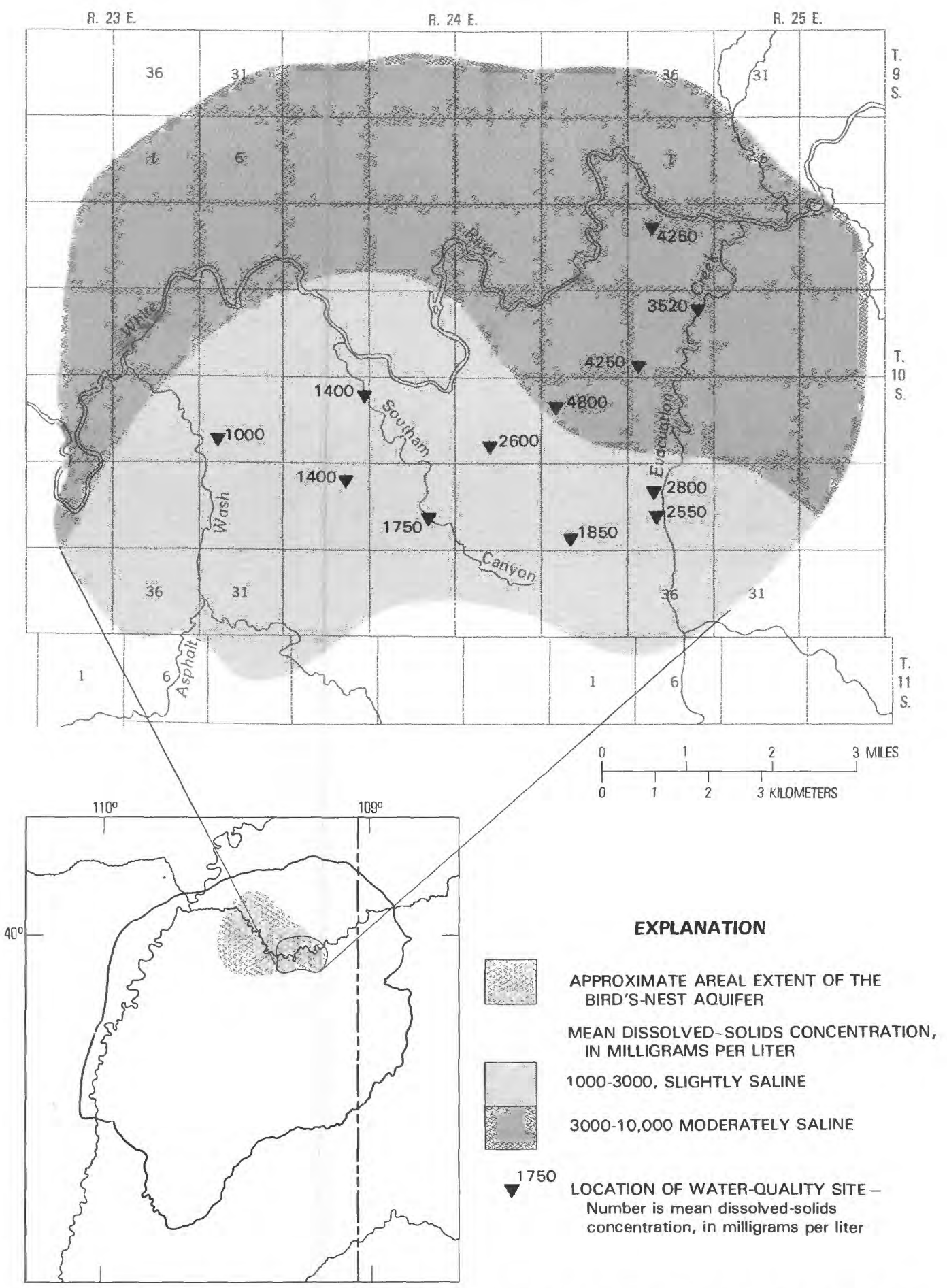

FIGURE 13.-General quality of water in the bird's-nest aquifer in the Parachute Creek Member of the Green River Formation.

Ground-water discharges from the bedrock aquifers to the alluvial deposits in the study area and a small quantity leaves the study area in the alluvium of the Green River. The quantity leaving the study area is considered to be equal to the quantity entering the study area in the alluvium in the White and Green Rivers.

\section{EVAPOTRANSPIRATION}

Evapotranspiration consumes most of the precipitation that falls on the southeastern Uinta Basin. Even in areas where runoff is large, evapotranspiration, on the 


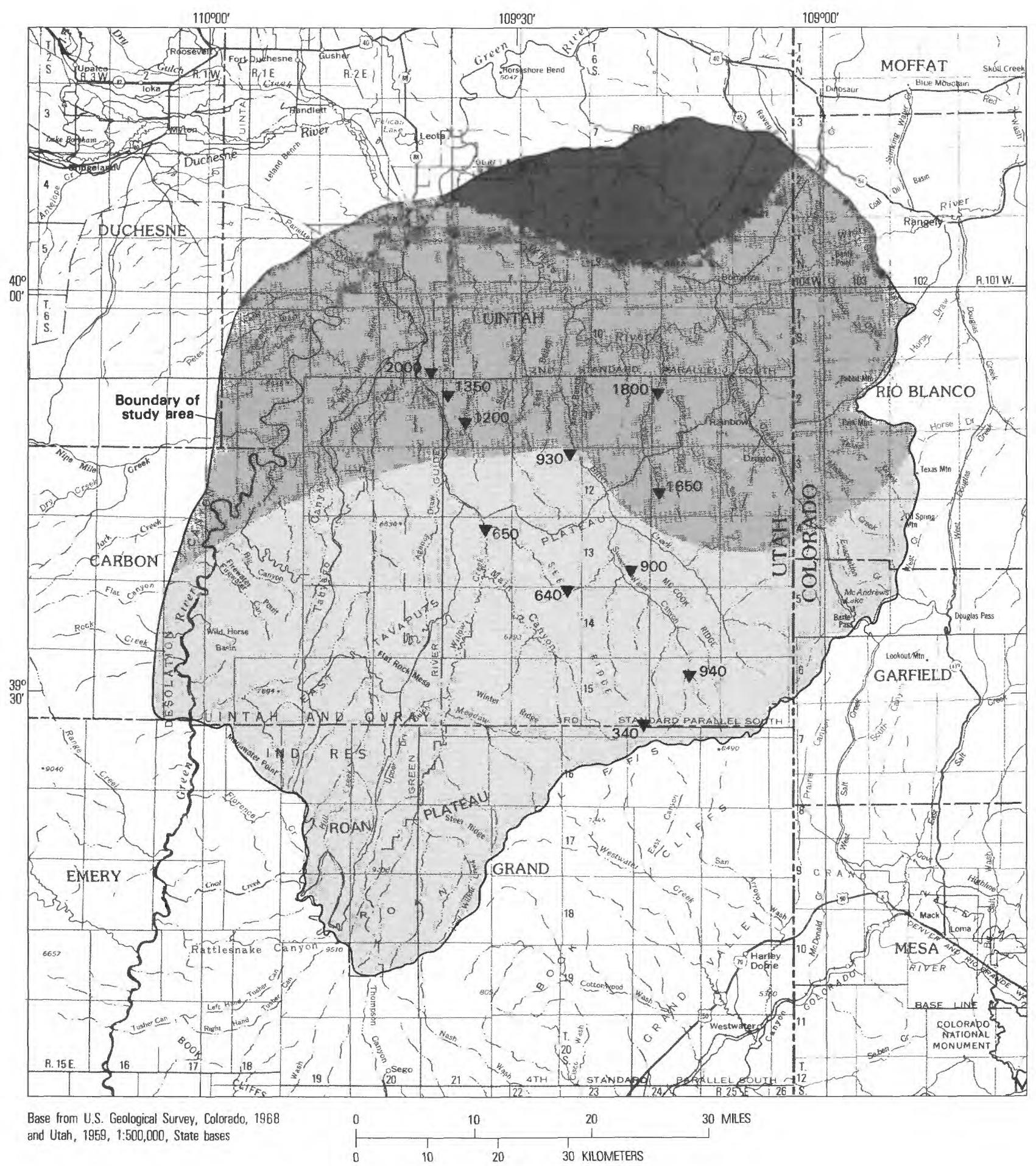

EXPLANATION

MEAN DISSOLVED-SOLIDS CONCENTRATION, IN MILLIGRAMS PER LITER

LESS THAN 1000 , FRESH

3000-10,000 MODERATELY SALINE

1000-3000, SLIGHTLY SALINE

940 LOCATION OF WATER-OUALITY SITE-

Number is mean dissolved-solids concentration, in milligrams per liter

FIGURE 14.-General quality of water in the Douglas Creek aquifer. 
average, consumes about 90 percent of the annual precipitation. The largest unit runoff gaged was 1.6 inches for an 11.7-square-mile area in the headwaters of Bitter Creek (Lindskov and Kimball, 1982, table 2), where the average precipitation is about 17 inches. In comparison, of the average of 11 inches that fall on the entire study area, an average of 0.2 inch flows to the White and Green Rivers. Thus, about 98 percent (10.8 inches or 1.76 million acre-feet) of the precipitation that falls on the area is returned directly to the atmosphere.

Although evapotranspiration from some alluvial aquifers may equal or exceed 18 inches during an average year (Holmes and Kimball, 1983), the total water consumed by evapotranspiration from the alluvial aquifers throughout the study area is only about 28,000 acrefeet-less than 2 percent of the total evapotranspiration in the area.

Annual evapotranspiration tends to be more constant than annual precipitation. Variations for precipitation and potential evapotranspiration at Fort Duchesne, Utah, for 1943-75 are shown in figure 15. The annual potential evapotranspiration exceeds precipitation during the entire period of record. The difference ranges from 15.3 inches during the wettest year (1965) to 41.3 inches during the driest year (1974). The difference accounts for the small runoff observed from the intra-area streams, and it also indicates that an increase in precipitation does not always produce much increase in runoff.

Evapotranspiration causes a deterioration of the chemical quality of both surface water and ground water in alluvium. Solutes are concentrated by evapotranspiration, and in some cases-notably in Bitter Creek-the water becomes very saline (figs. 11 and 12).

\section{SUMMARY OF INTRA-AREA WATER BUDGET}

The water budget for the components of the hydrologic cycle that originate within the study area has been expressed in equation (2) as

$$
P=E T+R O+G W_{ \pm} \text {storage changes. }
$$

Substituting values previously discussed gives, in inches, $11=10.8+0.2+0 \pm$ storage changes.

There is practically no surface storage in the area. Although the combined recoverable storage in the three aquifers is about 18 million acre-feet, the present rate of withdrawal from wells is so small that there is no longterm change in ground-water storage. Thus, total annual storage changes in the area are considered to be zero.

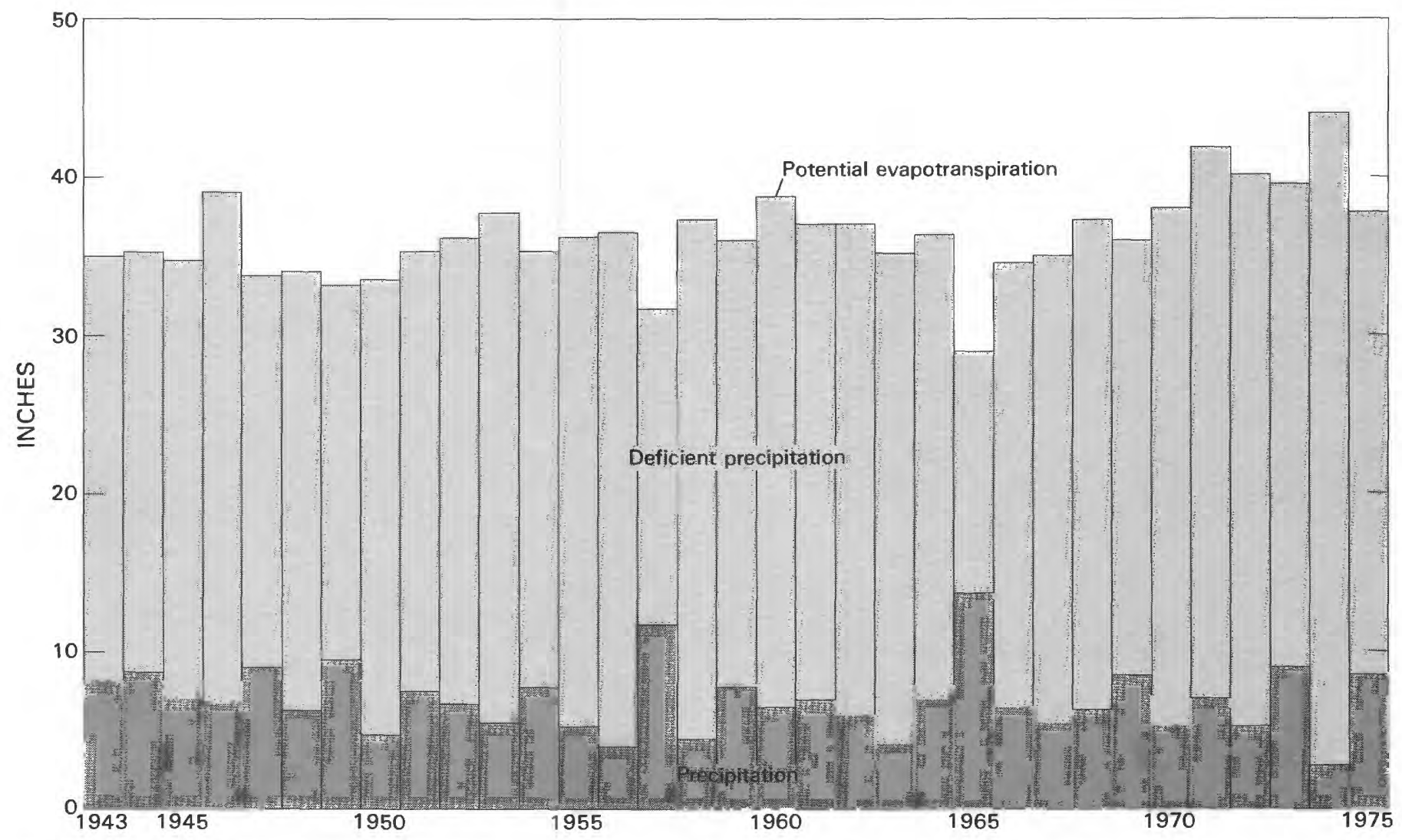

FIGURE 15.-Annual precipitation and potential evapotranspiration at Fort Duchesne, Utah, 1943-75. Potential evapotranspiration is considered to be 0.70 times pan evaporation (Hjelmfelt and Cassidy, 1975, p. 171-172). 


\section{WATER REQUIREMENTS FOR AN OIL-SHALE INDUSTRY}

The U.S. Department of the Interior (1973) assumed that 17 mines and plants might be involved in the production of 1 million barrels per day of oil from oil shale in the Green River Formation in Colorado, Utah, and Wyoming. Mining was envisioned that would produce more than 50,000 tons per day of oil shale from an underground mine and more than 100,000 tons per day from an open-pit mine. The shale would then be retorted on the surface. Underground (in situ) retorting techniques that require no mining also are envisioned, as are combinations of underground mining and in situ retorting. The water requirements will depend on the type of mining and the size of the industry.

\section{ABOVEGROUND PROCESSES}

Baughman (1978, p. 67-104) provides the history and a brief description of 11 patented aboveground-retorting processes. Included are the N-T-U (Nevada-Texas-Utah) process, Gas Combustion process, Kiviter process (U.S.S.R.), Petrosix process, Lurgi-Ruhrgas process, TOSCO II process, Superior Oil process, Galoter process (U.S.S.R.), Hydrogen Retorting, Union Oil process, and Paraho process. According to Davis and Wood (1974), the three most advanced types of retorts for heating oil shale are the Union Oil process, the Gas Combustion process, and the TOSCO II process.

The water requirements for each process varies considerably. For example, the TOSCO II process assumes that the retorted shale is compacted and cemented with water, whereas in the Paraho process the retorted shale is compacted without water. The water requirement for the Paraho process is mainly for revegetation, whereas in the TOSCO II process, it is largely for compaction.

Depending upon the process, the total quantity of water required by a unit-size $(100,000$ barrels per day) oilshale mine ranges from about 13,400 to 20,100 acre-feet per year (Davis and Wood, 1974, p. 9). The average water requirements for mining, surface retorting, upgrading, disposal of retorted shale, and other associated uses are listed in table 1.

\section{IN SITU PROCESSES}

Baughman (1978, p. 104-111) describes eight in situ processes. They include processes developed by Talley Energy Systems, Geokinetics, Inc., Equity Oil Co., Laramie Energy Research Center, Dow Chemical Co., Occidental Petroleum Corp., the Lawrence Livermore Laboratory, and the Nuclear In situ process.
TABLE 1.-Summary of water requirements for a 100,000-barrelper-day oil-shale mine with retorting above ground Adapted from Davis and Wood, 1974, p. 9-10

\begin{tabular}{|c|c|c|c|}
\hline \multirow{2}{*}{ Category } & \multicolumn{2}{|c|}{ Average requirement } & \multirow{2}{*}{$\begin{array}{l}\text { Range in requirement } \\
\text { (Acre-feet per year) }\end{array}$} \\
\hline & $\begin{array}{l}\text { (Acre-feet } \\
\text { per year) }\end{array}$ & $\begin{array}{l}\text { (Barrels of water } \\
\text { per barrel of oil) }\end{array}$ & \\
\hline Mining and crushing & 890 & 0.2 & $600-900$ \\
\hline Retorting & 1,290 & .3 & $900-1,500$ \\
\hline Shale-oil upgrading & 3,710 & .8 & $1,700-4,400$ \\
\hline Processed-shale disposal & 7,270 & 1.5 & $2,400-8,400$ \\
\hline Power requirements & 1,780 & .4 & $1,000-4,500$ \\
\hline Revegetation & 350 & .1 & $0-1,800$ \\
\hline $\begin{array}{l}\text { Miscellaneous, including } \\
\text { associated urban use }\end{array}$ & 1.600 & .3 & $1,000-2,000$ \\
\hline Total & 16,890 & 3.6 & \\
\hline
\end{tabular}

TABLE 2.-Summary of water requirements for a 100,000-barrelper-day oil-shale mine with retorting by the Occidental modified in situ process

Adapted from Nowacki, 1981, p. 254

\begin{tabular}{lrc}
\hline \multirow{2}{*}{ Category } & \multicolumn{2}{c}{ Average requirement } \\
\cline { 2 - 3 } & $\begin{array}{c}\text { (Acre-feet } \\
\text { per year) }\end{array}$ & $\begin{array}{c}\text { (Barrels of water } \\
\text { per barrel of oil) }\end{array}$ \\
\hline Mining and crushing & 966 & 0.2 \\
Retorting and shale-oil upgrading & 5,004 & 1.1 \\
Process-shale disposal and revegetation & 2,206 & .5 \\
Power requirements & $(1)$ & $(1)$ \\
Miscellaneous, including associated urban use & 1,550 & .3 \\
\multicolumn{1}{c}{ Total } & 9,726 & 2.1 \\
\hline
\end{tabular}

1 Not applicable for project or site analyzed.

The water requirements for in situ processes are considerably less than those for aboveground processes because a large part of the requirement for aboveground retorting is for dust control during disposal of the retorted shale. This is apparent by comparing table 1 with table 2, which shows average water requirements for the various categories of in situ processing.

\section{TOTAL REQUIREMENTS}

It is not known how much oil shale eventually will be mined and processed in the southeastern Uinta Basin. The U.S. Department of the Interior (1973) envisioned a 1-million-barrel-per-day national industry, but in 1979, the Carter Administration declared a national goal of 400,000 barrels per day by 1990 . At this time (1982), the total production in the southeastern Uinta Basin is approximately 150 barrels per day from an experimental plant operated by Geokinetics, Inc.

About 80 billion barrels of shale oil in the southeastern Uinta Basin is recoverable through presently known technology (Probstein and Gold, 1978, p. 247). This is about 15 percent of the shale oil in the Green River Formation. If the daily production were about 150,000 barrels, the reserves would last nearly 1,500 years. Planned oil-shale mining (fig. 16) by White River Shale Oil Corp. 


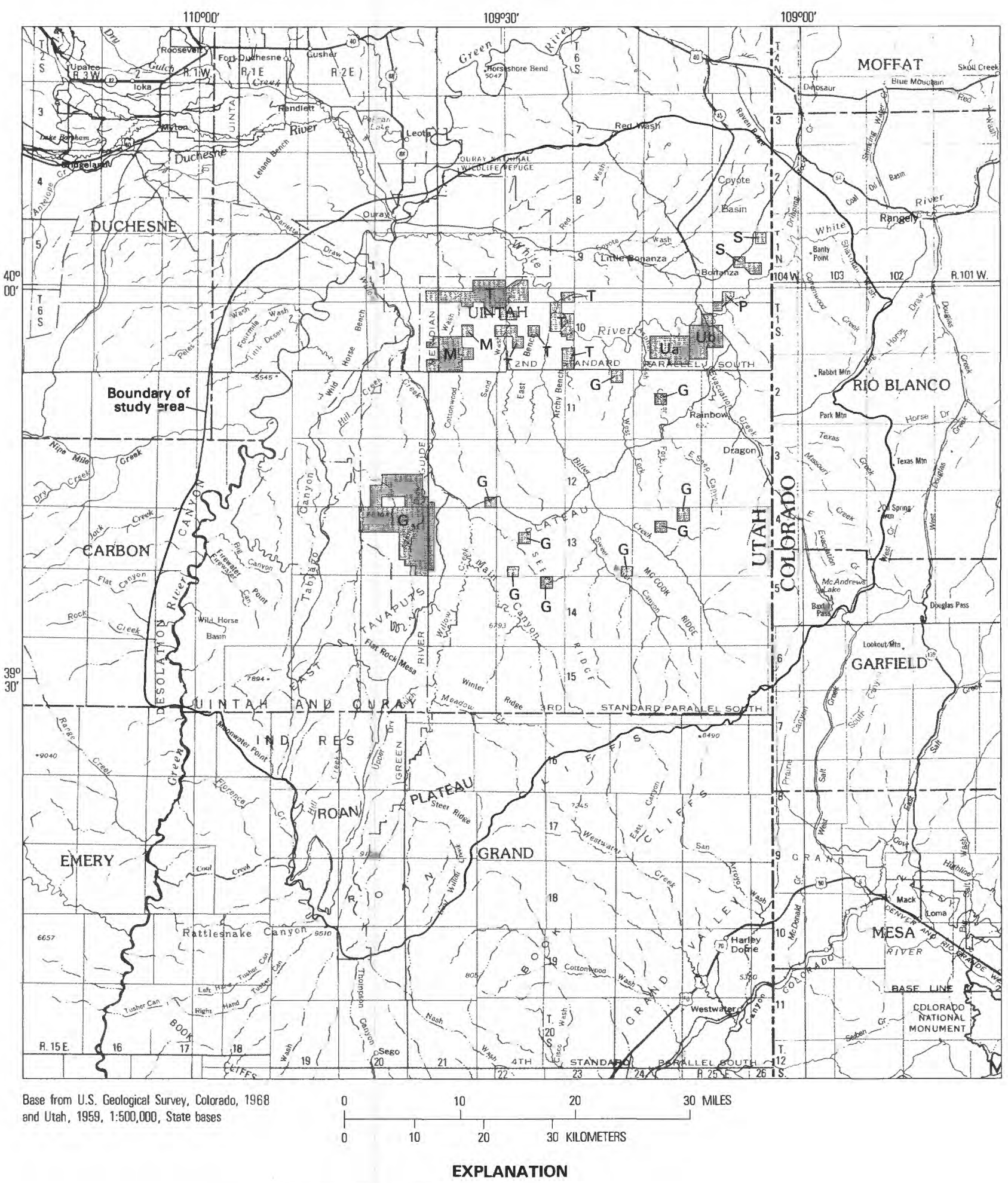

PROPOSED AREAS OF OIL-SHALE MINING (1981)

\begin{tabular}{lll}
\hline$T$ & TOSCO CORP. \\
\hline M & MAGIC CIRCLE ENERGY CORP. \\
\hline$P$ & PARAHO DEVELOPMENT CORP. \\
\hline
\end{tabular}

SYNTANA-Utah project

(Quintana Minerals Corp.) GEOKINETICS, INC.

FIGURE 16. - Proposed areas of oil-shale mining (1981). 
(Federal lease tracts Ua and Ub), TOSCO Corp., Paraho (U.S. Department of Energy project), and Geokinetics, Inc., has the potential to produce 170,000 barrels per day. With additional leasing, production could more than double and attain a peak of 400,000 barrels per day. This 400,000 barrels per day would deplete the reserves in about 550 years.

The peak production of 400,000 barrels per day should not require more than 67,600 acre-feet of water per year, assuming aboveground retorting with an average of 3.6 barrels of water used for each barrel of oil produced. Thus, unless otherwise stated, a water requirement of about 70,000 acre-feet per year for peak production of shale oil is used in this report when comparing watersupply options and evaluating long-range impacts on the water resources of the area. The U.S. Department of the Interior (1973) envisioned 4 in situ mines and 13 surface mines. Even if one-half the shale were mined using modified in situ methods, the water requirements for producing 400,000 barrels of oil per day would be 54,000 acre-feet per year.

A small percentage of the total water requirements will be produced by mining activities. Water will be produced from drainage of the aquifer above the mining zone while sinking shafts, from dewatering the mining zone, and from retorting. For the southeastern Uinta Basin, the quantity of drainage from above the mining zone at the Federal lease tracts $\mathrm{Ua}$ and $\mathrm{Ub}$ was estimated by Holmes and Kimball (1983) to be about 1,500 acre-feet per year or 900 gallons per minute for one shaft. During or after completion of the shaft, grouting would eliminate this drainage. Little is known about the hydraulic characteristics of the mining zone, but there is no indication that the oil shale contains or will transmit appreciable quantities of water. It seems reasonable to assume, therefore, that if any dewatering is necessary, total pumpage for a 100,000-barrel-per-day mine would not exceed 1,500 acre-feet per year per shaft. Finally, the water produced during retorting probably would not exceed one-third barrel per barrel of oil. Furthermore, the quality of the retort water may limit its use. Thus, the water produced during mining in the southeastern Uinta Basin probably will not provide large supplies for oil-shale processing.

\section{SELECTED SOURCES OF WATER SUPPLY FOR AN OIL-SHALE INDUSTRY}

Utah's unused share of water in the Colorado River system in 1980 was about 500,000 acre-feet per year (Utah Division of Water Resources, 1980, p. 43). This is more than seven times the estimated peak requirement for an oil-shale industry in Utah. Numerous options are available for developing the necessary water supplies, and some of these options are discussed in the following sections.

\section{WHITE RIVER}

\section{NATURAL FLOW}

The natural flow of the White River during most years could provide the estimated 70,000 acre-feet (97 cubic feet per second) of water that may be needed for an oilshale industry. Discharge rates of less than 97 cubic feet per second would occur for an average of only 1 day once every 8 years (fig. 17) or for 1 week once about every 20 years. These low-flow conditions generally are during July-August and December-January (fig. 18). Thus, on the basis of the present anticipated needs for an oil-shale industry, the required water supply generally could be taken directly from the river, even if no storage facilities were available.

A water supply derived from the natural flow of the White River may be affected by a proposed compact and future water-resource development in Colorado. The Ute Indian Tribe of Fort Duchesne, Utah, has prime water rights on the White River under the Winters Doctrine (Winters v. United States, 207 U.S. 564, 52 L. Ed. 340, 28 S. Ct. 207,1908 ), with a potential to irrigate 12,833 additional acres of land. A bill was passed endorsing a Ute Indian Water Compact during the 1980 session of the Utah Legislature. The proposed compact between the Tribe and Utah, which was authorized and approved by the State but not yet (1982) ratified by the Tribe, would allocate 62,000 acre-feet per year ( 86 cubic feet per second) to the Tribe. In addition, no interstate compact between Colorado and Utah regulates the water of the White River. Thus, water use upstream in Colorado may deplete the flow in the White River in the southeastern Uinta Basin.

\section{REGULATED FLOW}

WHITE RIVER DAM

The Utah Division of Water Resources has proposed an earthen dam (fig. 19) across the White River which would create a 13.5-mile reservoir (White River reservoir, fig. 19) and flood about 1,860 acres. The reservoir would have a total capacity of 105,000 acre-feet, of which 67,500 acre-feet would be active storage (U.S. Bureau of Land Management, 1980, p. 1). The main purpose of the reservoir would be to assure water for energy development, including oil shale. Potential users of the reservoir mentioned by the U.S. Bureau of Land Management 


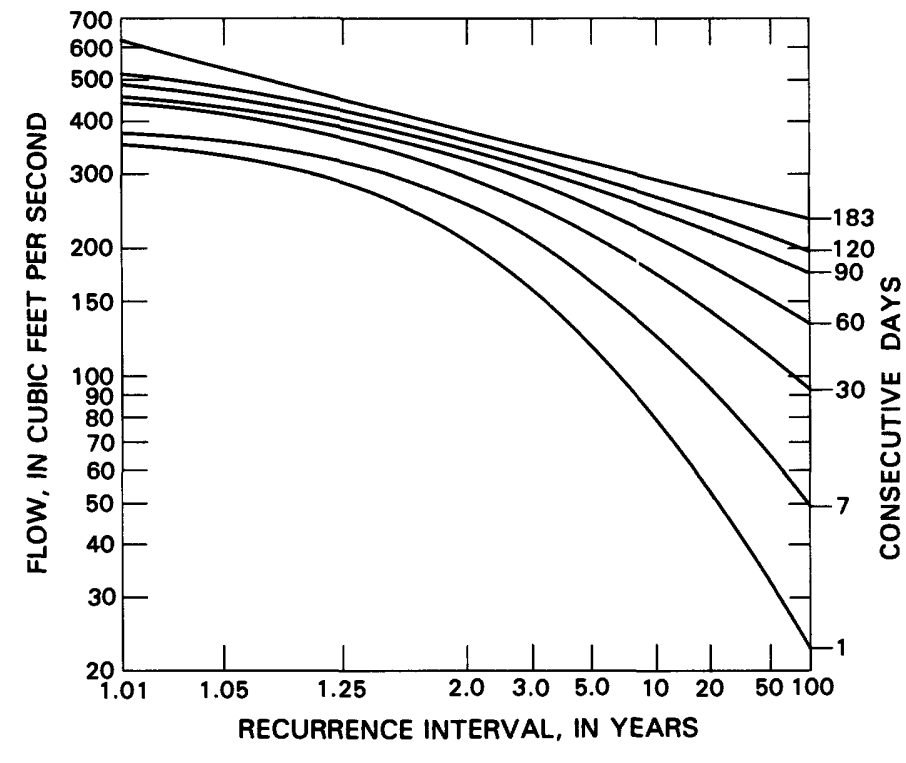

FIGURE 17.-Magnitude and frequency of annual low flows at station 09306500, White River near Watson. (Lindskov and Kimball, 1982, fig. 29.) quirements needed for an oil-shale industry -97 cubic feet per second (equivalent to 70,000 acre-feet per year) - only 1 day, on the average, in every 8 years or for 1 week every 20 years. During years of average or above average flow, all required water could be pumped or diverted directly from the White River. When flows in the White River are less than the quantities needed, releases from the reservoir in Hells Hole Canyon could satisfy the deficiencies.

The 25,000-acre-foot reservoir proposed in Hells Hole Canyon would inundate only about 260 acres of oil shale. In addition, this smaller reservoir would have less environmental impact than a reservoir on the White River.

\section{GREEN RIVER}

The 70,000 acre-feet per year of water could be pumped directly from the Green River (U.S. Bureau of Land Management, 1980, p. 2). The water could be released about 120 miles upstream from Flaming Gorge Reservoir into the Green River and pumped out of the river into a pipeline about 5 miles south of Jensen, Utah (fig. 19). The pipeline would deliver the water to the White River near the proposed White River Dam. Structures necessary to transport the water from the Green River to the White River include a river pumping station, settling pond and sluiceway, two highlift pumping stations, and about 28 miles of buried steel pipeline. Although there appear to be fewer constraints when compared to other alternatives, the prorated annual cost for delivering the water is greater (U.S. Bureau of Land Management, 1980, p. 165).

\section{GROUND WATER}

Three aquifers could be pumped to supply water for an oil-shale industry. According to Holmes and Kimball (1983), the recoverable water in storage is 0.2 million acre-feet in alluvium, 1.9 million acre-feet in the bird'snest aquifer, and 16 million acre-feet in the Douglas Creek aquifer.

Although it appears that ground water in storage could supply 70,000 acre-feet per year for more than 200 years, yields of individual wells and interference between wells limit maximum withdrawals from the aquifers. Holmes and Kimball (1983), for the areas shown in figure 20, determined that the maximum annual yields for 20 years of pumping would be about 20,000 acre-feet for the bird'snest aquifer and about 1,400 acre-feet for the Douglas Creek aquifer. Thus, although it appears that ground water could meet only a small part of the demand, it could
Water pumped from the White River during high-flow periods to a reservoir in Hells Hole Canyon (fig. 19) could be used during low-flow periods to supplement water pumped directly from the White River (U.S. Bureau of Land Management, 1980, p. 2). As stated previously, the daily flow in the White River is less than the peak re-
(1980, p.1) are the White River Shale Oil Corp. $(13,000$ to 26,000 acre-feet per year), TOSCO Corp. $(18,000$ acrefeet per year), Moon Lake powerplant (18,000 acre-feet per year).

oil-shale deposits which would become unavailable for mining. An historic site, the Ignatio Stage Stop and posmany archeological remains would be inundated by the reservoir. The impacts on downstream water resources are discussed later.

\section{OFF-STREAM STORAGE IN HELLS HOLE CANYON}




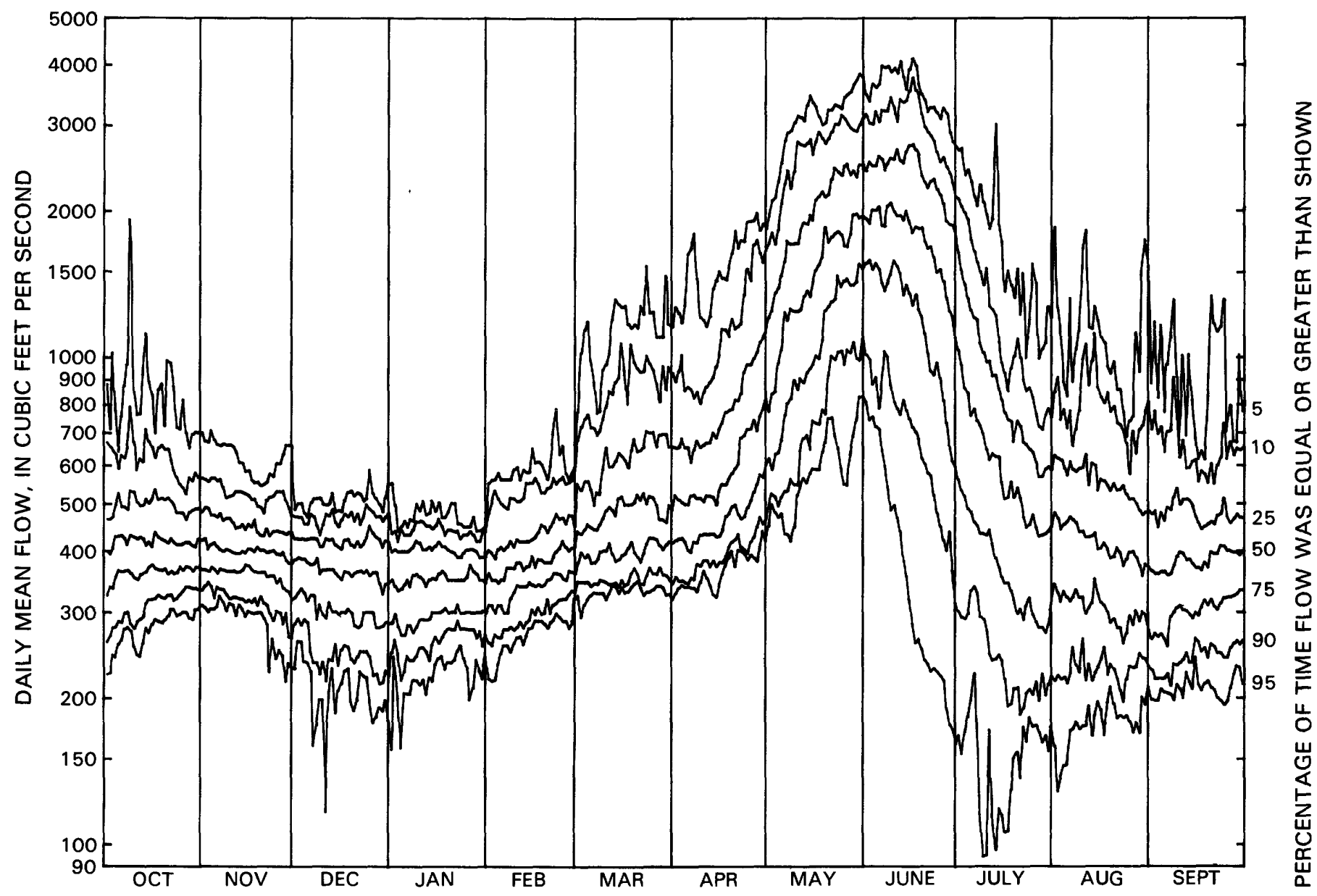

FIGURE 18.-Daily-duration hydrographs for indicated percentage of time flow at station 09306500 , White River near Watson, was equal to or greater than that shown. (Lindskov and Kimball, 1982, fig. 27.)

be used in conjunction with surface water, thus decreasing the required surface storage and satisfying much of the demand for experimental plants and public supply.

Ground and surface water are hydraulically connected in the study area. Holmes and Kimball (1983) indicated that after 20 years of pumping 10,000 acre-feet per year from the bird's-nest aquifer, more than one-half the water would be coming from leakage from the overlying Uinta Formation and induced infiltration into the aquifer from the White River. Long-term withdrawals from the alluvium also would decrease streamflow in many tributaries. However, it appears that pumping from the Douglas Creek aquifer would have little, if any, effect on flows in the White or Green Rivers.

\section{POTENTIAL IMPACTS OF AN OIL- SHALE INDUSTRY ON WATER RESOURCES}

An oil-shale industry could have many impacts on the water resources of the southeastern Uinta Basin. The consumptive use of the water could deplete the supply for other water users, and the water quality also could be directly or indirectly affected. Direct effects could include the accidental release of retort or leachate waters to the surface or ground water of the area, and the failure of holding ponds for retorted shale and process waters. Indirect effects include construction, mining, processing, and disposal activities. These impacts are discussed below in terms of water supply and water quality. 


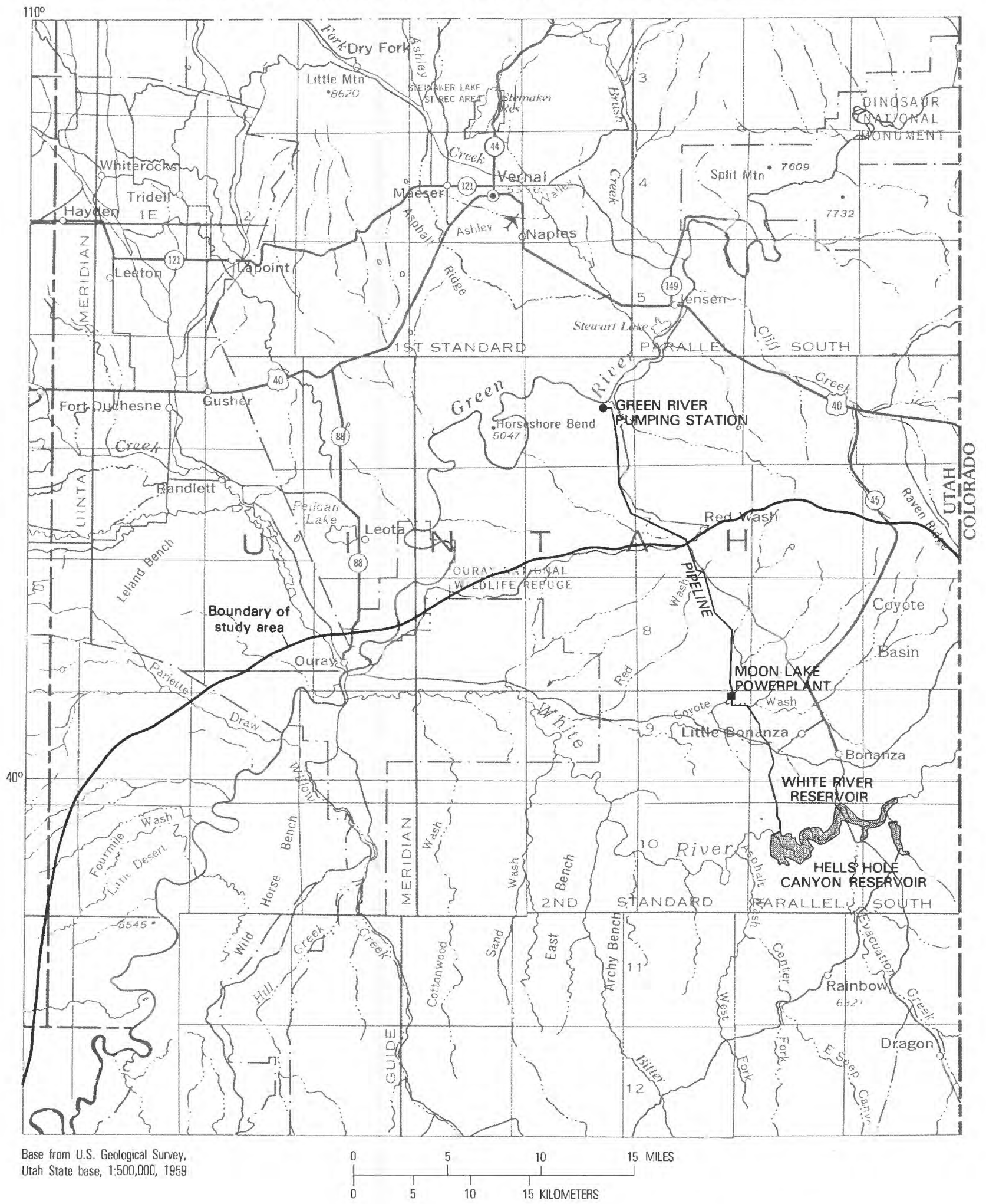

FIGURE 19.-Location of proposed projects that may be associated with an oil-shale industry. 


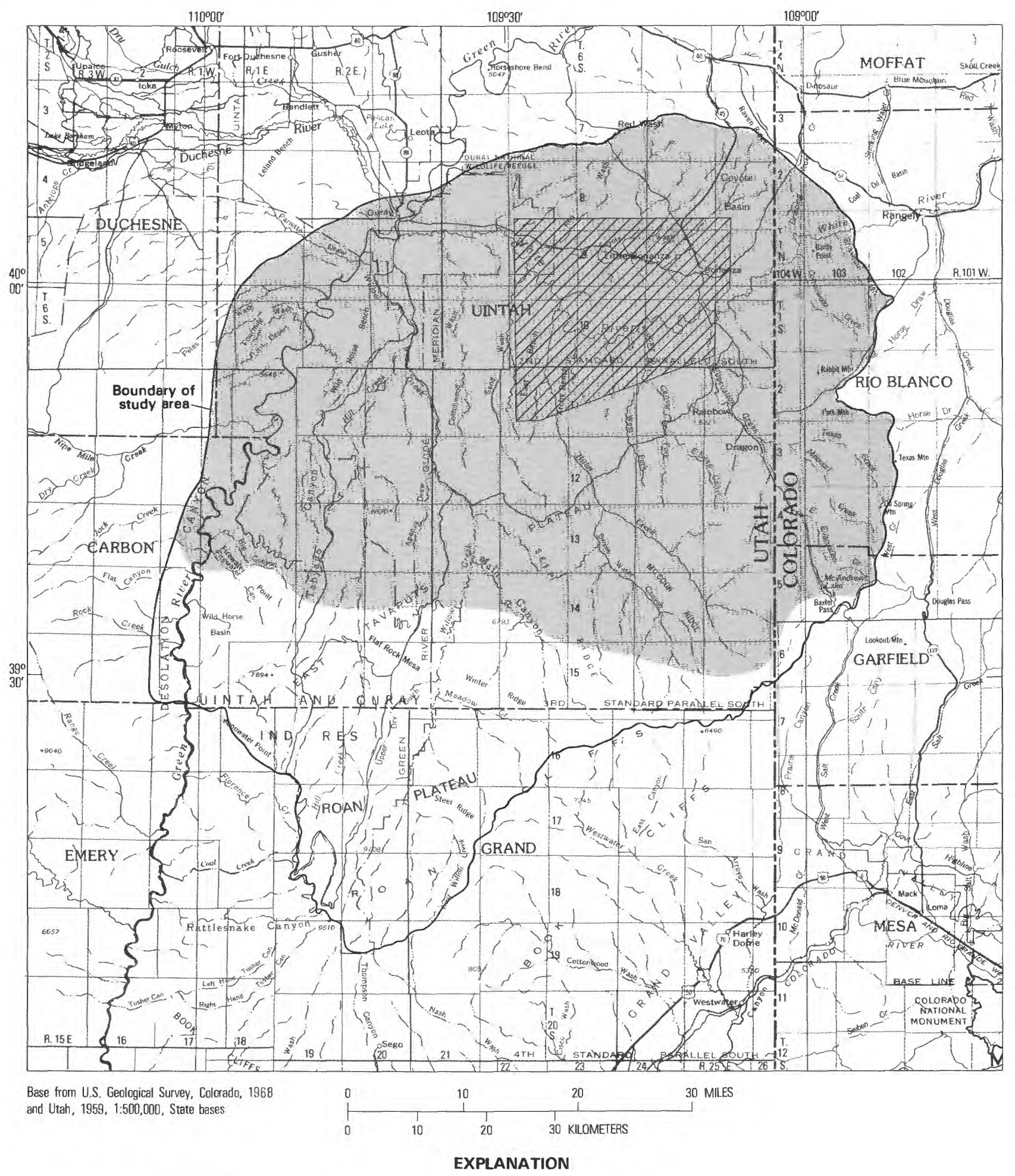

BIRD'S-NEST AQUIFER IN PARACHUTE CREEK MEMBER OF THE GREEN RIVER FORMATION

DOUGLAS CREEK AQUIFER

FIGURE 20.-Approximate areal extent used in determination of maximum annual yields from the consolidated-rock aquifers. 


\section{WATER SUPPLY}

The use of any part of Utah's share of the flow in the Colorado River Basin for an oil-shale industry competes with other potential uses such as irrigation, public supply, and other industrial uses.

An oil-shale industry in the southeastern Uinta Basin that produced 400,000 barrels of oil per day could increase the annual consumptive water use in the Upper Colorado River Basin by about 70,000 acre-feet. This oil production would be only 13 percent of the 3 million barrels of oil equivalent from a synfuels industry that the water resources of the Upper Colorado Region can support (U.S. Water Resources Council, 1981, p. 35054); however, the Council concludes that:

Synthetic fuels development in some development areas will be limited unless additional water supply measures (i.e., reservoirs, water imports, groundwater) are developed. The White River area in Colorado and Utah with large oil shale reserves is of particular concern.

Provisions of the Compact among the Upper Basin States, which allocates water supplies among the States, may ultimately constrain synfuels development. Specifically, conversion of coal mined from the Four Corners area in New Mexico and both coal and oil shale conversion in Colorado, may ultimately be limited by those constraints.

\section{WATER QUALITY}

An oil-shale industry could have beneficial or detrimental effects on the water quality in the southeastern Uinta Basin. The use of water of poor quality from surface or ground-water sources could decrease the quantity of poor-quality water that reaches the White or Green Rivers, thus eventually decreasing the salt load of the Colorado River. However, the salt load could increase from the activities of an oil-shale industry. The detrimental effects on water quality can best be discussed in terms of the sediment load and the dissolved constituents in the water.

\section{SEDIMENT}

\section{POTENTIAL EFFECTS OF THE WHITE RIVER DAM}

The proposed White River Dam could cause significant changes in the erosion and sediment regime of the river downstream from the dam. In the downstream 18 miles of the river, about 1,040 acre-feet of bed material is scoured and filled during the 2-year flood (Seiler and Tooley, 1982, p. 15). The proposed reservoir would trap about 90 percent of the sediment moving in the stream (Grenney and Kraszewski, 1980, p. 4; Utah Division of Water Resources, 1979, p. 42) and in turn would release a large quantity of almost sediment-free water. Channel degradation of the reaches downstream from the dam could result because the material eroded during spring runoff would no longer be replaced. Increased bank erosion and channel migration of the river also could result from the large change in the sediment regime. If deepening of the White River channel occurs, there also could be increased erosion at the mouths of its tributary streams.

\section{POTENTIAL EFFECTS OF OIL-SHALE PROCESSING FACILITIES}

Sheet-erosion rates in the southeastern Uinta Basin are reportedly as large as 2.2 acre-feet per square mile per year (Seiler and Tooley, 1982, p. 37); but sediment yield to the White River is less than might be expected because of the small runoff. If process water from retort operations or water used in the construction of surface facilities is discharged into a normally dry streambed, increased channel erosion and sediment transport could result. Disturbance of the soil during construction of surface facilities could cause increased sediment transport by runoff. This problem could be minimized if construction is completed before the beginning of the late summer thunderstorm season.

Other sediment-related problems could result from the disposal of retorted-shale residue. Oil shale increases in volume by at least 20 percent during surface retorting. Thus, not all the shale can be backfilled in mines; and, furthermore, surface disposal of the retorted shale is less expensive than backfilling the shale into the mine. Sediment yields from surface piles of retorted oil shale are reported to be large (Colorado State University, 1971, table 11). During simulated rain of 0.54 inch per hour, an uncompacted pile of retorted oil shale on a grade of 0.75 percent ( 40 feet per mile) had a sediment yield of more than 0.3 ton per acre per hour, or 0.1 acre-foot per square mile per hour. Yield from the same pile after compaction was about 0.1 ton per acre per hour during a simulated rain with an intensity of 0.4 inch per hour. Sedimentyield rates from actual disposal piles can be expected to be greater because the grades of the piles will be steeper than 0.75 percent. The maximum 2-year rain intensity in the Uinta Basin is about 0.6 inch per hour (Miller and others, 1973), so rain intensities similar to those used in the Colorado State University study are reasonable and common.

Impounding ponds would be necessary to prevent sediment from the surface-processing sites and the retortedshale disposal areas from being transported into the 
White River during storm runoff. Sheet-erosion rates during construction of the surface facilities are expected to be great; thus, the retaining ponds would need to be completed early in the development period to protect the White River and tributary streams from sediment transported by thunderstorm runoff from the construction sites.

The impounding ponds need to have sufficient capacity to retain 100 percent of the runoff from the 100 -year, 24-hour storm in order to prevent contamination of the White River. Because of their potential for rapid filling, the cleaning of these ponds would be important. Runoff from a small storm could transport enough sediment into the ponds so as to render them incapable of containing the sediment from later, and possibly more intense storms. The ponds would need to be inspected after every storm to determine if adequate storage space for sediment remained.

\section{DISSOLVED CONSTITUENTS}

The salinity of the Colorado River system could be affected by the development of an oil-shale industry, and any change in salinity would cause economic consequences for downstream users. A 1-million-barrel-perday oil-shale industry would increase the salinity of the Colorado River at Hoover Dam from 10 to 15 milligrams per liter of dissolved solids (U.S. Department of the Interior, 1973, p. 34). A prorated projection ranges from 4 to 6 milligrams per liter for the salinity increase from a 400,000-barrel-per-day oil-shale industry in Utah. The increase in salinity could result from construction, mining, processing, and disposal activities associated with the industry.

Construction activities generally increase the exposure of the natural waters in the basin to fresh material, which then can be leached and weathered by natural processes. Mining will necessitate drainage of the oil-shale zones. The water drained from these mines may be of poor quality. Releasing this water to streams or into other aquifers could increase the salinity of the surface or ground water.

Because of the potential impacts on water quality, disposal of retorted shale is an important concern. The potential to increase sediment loads has been mentioned above. Studies by Ward and others (1971) and Ward and Reinecke (1972) have analyzed the leaching potential of retorted shale piles. Each study found that the concentrations of various solutes in the leachate, particularly sodium and sulfate, were large.

The processing of oil shale produces "retort" water, which also could have adverse impacts on the environment. The chemical composition of four retort waters in contrast with some natural waters of the southeastern Uinta Basin is compared in table 3. The chemical concentration of the four retort waters differ, but each of them differs considerably from any of the natural waters.

\section{DISSOLVED SOLIDS}

The retort waters have greater dissolved-solids concentrations than the natural waters of the southeastern Uinta Basin. Any mixing of the retort waters with the natural waters would degrade the latter. Not only are the dissolved-solids concentrations large in retort waters, but the unusual concentrations of certain constituents may have particular adverse impacts on water quality. Selected constituents are discussed below.

\section{TOTAL ORGANIC CARBON}

Organic carbon in the form of oil, grease, and other substances is an obvious product of the retorting process. Although concentrations of organic carbon in the natural waters are large because of the abundant organic material in the Green River Formation, the concentrations in retort waters far exceed the natural concentrations.

Stuber and Leenheer (1978) evaluated the various types of organic substances in both retort and natural waters of the Uinta Basin. They found that the organic substances in samples collected from natural surface waters were mostly humic and fulvic acids, other naturally occurring acids (hydrophobic and hydrophillic acids), and lesser quantities of proteins, amino acids, and sugars, as well as oil and grease. The retort waters, however, contain hydrocarbons that do not occur naturally, particularly aromatic amines (hydrophobic bases). The latter include carcinogens and mutagens (J. A. Leenheer, U.S. Geological Survey, oral commun., 1979).

\section{MAJOR SOLUTES}

The concentrations of anions in retort waters are much greater than the corresponding concentrations in natural waters, whereas the concentrations of the common cations are less. Among the anions that are much greater are chloride, sulfate (and associated species), and alkalinity as bicarbonate and carbonate ions. The sulfate species that are important in certain retort waters have been studied by Stuber and others (1978). Waste waters from in situ processing were found to contain thiosulfate $\left(\mathrm{S}_{2} \mathrm{O}_{3}^{--}\right)$as the most abundant species and large concentrations of thiocyanate $\left(\mathrm{SCN}^{-}\right)$. These species, particularly thiocyanate, could persist in underground retorts and could pose a health hazard. 
TABLE 3.-Comparison of mean chemical composition of four retort waters with natural waters in the southeastern Uinta Basin Adapted from Lindskov and Kimball, 1982, tables 7-12; Holmes and Kimball, 1983, tables 8 and 11; and Nowacki, 1981, table 7.3

\begin{tabular}{|c|c|c|c|c|c|c|c|c|c|c|c|c|}
\hline & \multicolumn{4}{|c|}{ Retort Waters } & \multicolumn{8}{|c|}{ Natural Waters } \\
\hline & $\begin{array}{c}\text { TOSCO II } \\
\text { process }\end{array}$ & $\begin{array}{l}\text { Paraho } \\
\text { process }\end{array}$ & $\begin{array}{c}\text { NTU } \\
\text { process }\end{array}$ & $\begin{array}{l}\text { Modified } \\
\text { in situ } \\
\text { process }\end{array}$ & $\begin{array}{c}\text { Bird's-nest } \\
\text { aquifer }\end{array}$ & $\begin{array}{l}\text { Douglas } \\
\text { Creek } \\
\text { aquifer }\end{array}$ & $\begin{array}{l}\text { White } \\
\text { River }\end{array}$ & $\begin{array}{l}\text { Green } \\
\text { River }\end{array}$ & $\begin{array}{c}\text { Evacuation } \\
\text { Creek }\end{array}$ & $\begin{array}{l}\text { Bitter V } \\
\text { Creek H }\end{array}$ & $\begin{array}{l}\text { Willow and E } \\
\text { Hill Creeks }\end{array}$ & $\begin{array}{l}\text { Ephemeral } \\
\text { washes }\end{array}$ \\
\hline \multicolumn{13}{|c|}{ General characteristics } \\
\hline $\begin{array}{l}\text { Specific conductance } \\
\text { (micromhos per } \\
\text { centimeter at } 25^{\circ} \text { Celsius) }\end{array}$ & 120,000 & 16,000 & 49,600 & 82,250 & 3,660 & 2,140 & 730 & 833 & 4,180 & 6,000 & 1,120 & 980 \\
\hline pH (units) & 8.4 & 8.8 & 8.7 & 8.1 & 8.4 & 8.4 & 7.8 & 7.9 & 8.0 & 8.1 & 8.1 & 7.8 \\
\hline $\begin{array}{l}\text { Turbidity } \\
\text { (Nephelometric turbidity } \\
\text { units) }\end{array}$ & 40 & 15 & - & 86 & 560 & - & 190 & 350 & 440 & 18 & 480 & 890 \\
\hline \multicolumn{13}{|c|}{ Major constituents (milligrams per liter) } \\
\hline Calcium, dissolved (Ca) & 18 & 2.5 & 0.6 & - & 74 & 40 & 72 & 71 & 150 & 210 & 71 & 60 \\
\hline Magnesium, dissolved (Mg) & 30 & 2 & 3 & - & 90 & 38 & 25 & 30 & 150 & 300 & 52 & 9 \\
\hline Sodium, dissolved $(\mathrm{Na})$ & 30 & 2 & 210 & - & 740 & 480 & 83 & 76 & 690 & 1,070 & 110 & 110 \\
\hline Potassium, dissolved (K) & 3 & .4 & 8 & - & 5 & 2 & 2.7 & 3.1 & 7.0 & 6.8 & 2.8 & 4.6 \\
\hline Alkalinity, total as $\mathrm{CaCO}_{3}$ & 35,200 & 12,800 & - & 92,300 & 730 & 630 & 180 & 173 & 390 & 360 & 320 & 180 \\
\hline Sulfide, total as S & $<.5$ & 1,350 & 14 & 915 & 18 & 3 & .3 & - & .2 & .1 & .3 & .1 \\
\hline Sulfate, dissolved $\left(\mathrm{SO}_{4}\right)$ & 5,500 & 29 & 1,600 & 376 & 1,300 & 450 & 190 & 260 & 2,000 & 3,500 & 280 & 240 \\
\hline Chloride, dissolved (Cl) & 70,000 & 2,300 & 5,000 & 53 & 96 & 130 & 61 & 27 & 41 & 77 & 13 & 11 \\
\hline Fluoride, dissolved (F) & 5 & 3.1 & 31 & 5.1 & 2.2 & 3.3 & .3 & .4 & .8 & .6 & .4 & .4 \\
\hline Silica, dissolved $\left(\mathrm{SiO}_{2}\right)$ & 3 & 2 & 2 & - & 16 & 14 & 15 & 8 & 10 & 13 & 15 & 11 \\
\hline Dissolved solids ${ }^{1}$ & 297,100 & ${ }^{2} 11,500$ & 13,700 & 257,600 & 2,700 & 1,500 & 500 & 570 & 3,300 & 5,300 & 740 & 550 \\
\hline Suspended solids at & & & & & & & & & & & & \\
\hline $105^{\circ}$ Celsius & 70 & 1 & - & 50 & - & - & 2,100 & 3,100 & 16,000 & 510 & - & 34,000 \\
\hline \multicolumn{13}{|c|}{ Nutrients (milligrams per liter) } \\
\hline Nitrate, dissolved as $\mathrm{N}$ & 580 & 138 & 33 & - & 0.9 & 0.1 & 0.1 & 0.5 & 1.1 & 1.6 & 2 & $\overline{-}$ \\
\hline Nitrite, dissolved as $\mathrm{N}$ & .1 & .3 & - & - & - & - & .01 & 0 & .02 & .03 & .01 & - \\
\hline Nitrogen, ammonia, total as $\mathrm{N}$ & 31,700 & 3,390 & 18,200 & 38,000 & 1 & 1.5 & .05 & .05 & - & - & - & - \\
\hline Nitrogen, total as $\mathbf{N}$ & 33,600 & 5,100 & - & 30,300 & - & - & 1.5 & 1.8 & - & - & - & - \\
\hline Phosphorus, total $\left(\mathrm{PO}_{4}\right)$ & $<5$ & $<1$ & - & - & $<.1$ & 2 & 1.4 & 2.0 & .7 & 1.3 & 2.6 & - \\
\hline \multicolumn{13}{|c|}{ Trace elements, dissolved (micrograms per liter) } \\
\hline Aluminum (Al) & 2,400 & 360 & 110 & - & 70 & 40 & 20 & - & 21 & 60 & 26 & 140 \\
\hline Antimony (Sb) & $<900$ & - & 9 & - & $<1$ & 0 & - & - & - & - & - & - \\
\hline Arsenic (As) & $<5$ & .2 & 6 & 0.5 & 43 & 9 & 1 & 2 & 2 & 4 & 10 & 9 \\
\hline Barium (Ba) & $<300$ & - & 12 & - & 80 & 80 & $<100$ & $<100$ & $<100$ & $<100$ & $<100$ & - \\
\hline Boron (B) & 1,200 & 180 & 5,200 & - & 3,800 & 2,600 & 150 & 130 & 1,100 & 3,300 & 620 & 200 \\
\hline Cadmium (Cd) & $<900$ & - & - & - & $<1$ & $<1$ & - & - & - & - & - & - \\
\hline Chromium (Cr) & 300 & 20 & 11 & - & 20 & 10 & - & - & - & - & - & - \\
\hline Cobalt (Co) & 150 & - & 74 & - & 2 & 2 & - & - & - & - & - & - \\
\hline Copper $(\mathrm{Cu})$ & 9,000 & 70 & 8 & - & 40 & 3 & - & - & 15 & $<20$ & 23 & 21 \\
\hline Iron $(\mathrm{Fe})$ & 9,000 & 1,100 & 7,700 & - & 390 & 410 & 42 & 42 & 44 & 36 & 43 & 250 \\
\hline Lead $(\mathrm{Pb})$ & 300 & - & 120 & - & - & - & - & - & - & - & - & - \\
\hline Lithium (Li) & $<2,000$ & - & - & - & 410 & 320 & 12 & - & 82 & 100 & 22 & 25 \\
\hline Manganese (Mn) & 1,200 & 30 & 42 & - & 44 & 37 & $<10$ & $<10$ & 83 & 60 & 26 & 50 \\
\hline Mercury (Hg) & $<.1$ & $<.1$ & .1 & $<.1$ & $<1$ & $<1$ & - & - & - & $<.5$ & $<.1$ & - \\
\hline Molybdenum (Mo) & $<200$ & - & 56 & - & 30 & 2 & 2 & - & 31 & 27 & 17 & 18 \\
\hline Nickel (Ni) & 200 & 40 & 1,100 & - & 7 & 3 & 3 & - & 5 & - & - & - \\
\hline Silver $(\mathbf{A g})$ & 600 & 20 & - & - & $<1$ & $<1$ & - & - & - & - & - & - \\
\hline Strontium (Sr) & 600 & 120 & 7 & - & 380 & 1,500 & 830 & - & 3,400 & 3,700 & 960 & 1,300 \\
\hline $\operatorname{Tin}(\mathrm{Sn})$ & $<300$ & 140 & 8,900 & - & 30 & 30 & - & - & - & - & - & - \\
\hline Titanium (Ti) & $<200$ & - & 640 & - & 20 & 20 & - & - & - & - & - & - \\
\hline Vanadium (V) & $<300$ & - & 37 & - & 2 & 3 & 2 & - & 1 & 3 & 6 & 11 \\
\hline Zinc (Zn) & $<1,200$ & - & 260 & - & 40 & 30 & $<20$ & $<20$ & $<20$ & 63 & $<20$ & 73 \\
\hline \multicolumn{13}{|c|}{ Organic compounds (milligrams per liter) } \\
\hline Carbon, organic total as $\mathrm{C}$ & 19,300 & 15,000 & - & 12,300 & - & 20 & 14 & 18 & 14 & 24 & 24 & - \\
\hline Cyanide, dissolved as CN & $<.1$ & 12 & - & .2 & $<0.01$ & 0 & $<.001$ & - & $<.001$ & - & - & - \\
\hline Oil-grease, total & 964 & 392 & - & 1,430 & 3 & 2 & 1.5 & - & 4.0 & - & - & - \\
\hline
\end{tabular}

${ }^{1}$ Dissolved solids for natural waters are calculated from determined constituents.

${ }^{2}$ Calculated sum, differs from values reported in Nowacki $(1981$, p. 251, 252).

\section{NUTRIENTS}

Nutrient concentrations, particularly nitrogen species, are enriched in the retort waters. The most abundant species is ammonia, which indicates that the waters are greatly reduced in the retort process. Mixing retort waters with natural waters could cause reduction of other species. This could mobilize trace elements present as sediment coatings, which are insoluble precipitates when the waters are oxidized. 


\section{TRACE ELEMENTS}

Although some trace elements are more concentrated in retort waters than in natural waters, there is no consistent enrichment in the retort waters. The concentrations of trace elements in the natural waters are kept small by sorption and precipitation processes, which remove the trace elements from solution. It is possible that the trace-element concentrations also are small in the retort waters because of sorption and precipitation onto the retorted shale. The trace elements could be released if conditions change to produce a reducing acid environment.

\section{SUMMARY}

An oil-shale industry in the southeastern Uinta Basin could impact the area's water resources. Background hydrologic information obtained during 1974-80 was used to evaluate potential impacts from mining and the use of proposed alternative sources of water supply. Normal annual precipitation on the area averages 11 inches, but it varies with altitude from less than 8 inches below 5,000 feet to more than 20 inches where altitudes exceed 9,000 feet on the Roan Plateau. Streamflow in the higher altitudes is perennial; but in areas where precipitation is less than 10 inches, streamflow is ephemeral. Mean annual runoff from the area is about 28,000 acre-feet and ranges from less than 0.1 to 1.6 inches, depending on location. At any given site, runoff varies greatly from year to year and season to season. Potential evapotranspiration is large, exceeding precipitation in all years. A large increase in precipitation does not always produce a large increase in runoff or ground-water recharge.

Three aquifers in the study area contain a large quantity of water. Alluvial deposits of small areal extent are present in the major drainages. Consolidated-rock aquifers include the bird's-nest aquifer of the Parachute Creek Member of the Green River Formation, which is limited to the central part of the study area, and the Douglas Creek aquifer of the Douglas Creek Member of the Green River Formation, which underlies most of the area. Although the total recoverable water in storage in these aquifers is about 18 million acre-feet, maximum practical withdrawals would be limited to about 20,000 acre-feet per year.

The Green and White Rivers flow through the area and convey an average flow of 4.3 million acre-feet per year from an outside drainage of about 34,000 square miles. This is more than 150 times the flow that originates within the area.

An oil-shale industry in Utah with a peak production of 400,000 barrels of oil per day would require a water supply of about 70,000 acre-feet per year. Ground-water withdrawals in the area may be limited to about 20,000 acre-feet per year; thus alternative sources of supply were considered. Included were diversion from the natural flow of the White River, a proposed reservoir on the White River, diversion from the White River combined with proposed off-stream storage in Hells Hole Canyon, diversion from the Green River, and conjunctive use of surface and ground water.

Construction of a proposed dam on the White River would result in entrapment of about 90 percent of the sediment load moving in the river, which in turn would result in a release of nearly sediment-free water. Possible impacts are changes in channel gradient in the downstream 18 miles of the White River and changes in bank stability. In some areas, natural annual sheet-erosion rates are as great as 2.2 acre-feet per square mile. Because runoff is small, much of this eroded material is deposited in alluvial fans or along stream channels. If process water from retorting operations or water used in the construction of surface facilities is released into normally dry channels, increased channel erosion and sediment transport could result in tributary streams. This eventually would result in increased sediment loads in the White River. In addition, sediment yields from retorted shale piles contain large concentrations of sodium and sulfate, and the retort waters contain much organic carbon and nutrients. Without proper disposal of retort and leachate waters, a 400,000-barrel-per-day oil-shale industry in Utah could result in an increase in the salinity of the Colorado River at Hoover Dam by 4 to 6 milligrams per liter.

\section{REFERENCES CITED}

$$
\begin{gathered}
\text { Reports marked by an asterisk are part of the series that describe } \\
\text { hydrologic investigations in oil-shale areas } \\
\text { in the southeastern Uinta Basin }
\end{gathered}
$$

Baughman, G. L., compiler, 1978, Synthetic fuels data handbook (2nd ed.): Denver, Cameron Engineers, Inc., 438 p.

Bradley, W. H., 1930, The varves and climate of the Green River epoch: U.S. Geological Survey Professional Paper 158-E, 24 p.

Brobst, D. A., and Tucker, J. D., 1973, X-ray mineralogy of the Parachute Creek Member, Green River Formation, in the northern Piceance Creek Basin, Colorado: U.S. Geological Survey Professional Paper 803, 53 p.

*Butler, J. R., and England, J. L., 1979, Vegetation map of the southeastern Uinta Basin, Utah and Colorado: U.S. Geological Survey Miscellaneous Investigations Map I-1141, scale 1:126,720.

Cashion, W. B., 1967, Geology and fuel resources of the Green River Formation, southeastern Uinta Basin, Utah and Colorado: U.S. Geological Survey Professional Paper 548, 48 p.

1973, Geologic and structure map of the Grand Junction quadrangle, Colorado and Utah: U.S. Geological Survey Miscellaneous Geologic Investigations Map I-736, scale 1:250,000.

Cashion, W. B., and Donnell, J. R., 1974, Revision of nomenclature of the upper part of the Green River Formation, Piceance Creek Ba- 
sin, Colorado, and eastern Uinta Basin, Utah: U.S. Geological Survey Bulletin 1394-G, 9 p.

Colorado State University, 1971, Water pollution potential of spent oil shale residues: U.S. Environmental Protection Agency, Water Pollution Control Research Series 14030 EDB 12/71, 101 p.

*Conroy, L. S., 1979, Hydrologic and climatologic data, southeastern Uinta Basin, Utah and Colorado, water year 1977: U.S. Geological Survey Open-File Report 79-1493 (duplicated as Utah HydrologicData Report 33), 193 p.

*__ 1980, Hydrologic and climatologic data, southeastern Uinta Basin, Utah and Colorado, water year 1978: U.S. Geological Survey Open-File Report 80-1025 (duplicated as Utah Hydrologic-Data Report 34), $166 \mathrm{p}$.

*Conroy, L. S., and Fields, F. K., 1977, Climatologic and hydrologic data, southeastern Uinta Basin, Utah and Colorado, water years 1975 and 1976: Utah Basic-Data Release No. 29, 244 p.

Davis, G. H., and Wood, L. A., 1974, Water demands for expanding energy development: U.S. Geological Survey Circular 703, 14 p.

Desborough, G. A., Pittman, J. K., and Huffman, C., 1976, Concentration and mineralogical residence of elements in rich oil shales of the Green River Formation, Piceance Creek Basin, Colorado-A preliminary report: Chemical Geology, v. 17, p. 13-26.

Dyni, J. R., 1976, Trioctahedral smectite in the Green River Formation, Duchesne County, Utah: U.S. Geological Survey Professional Paper 967, 14 p.

Feltis, R. D., 1966, Water from bedrock in the Colorado Plateau of Utah: Utah State Engineer Technical Publication 15, 82 p.

Fenneman, N. M., 1946, Physical divisions of the United States: U.S. Geological Survey map, scale 1:7,000,000.

Goode, H. D., and Feltis, R. D., 1962, Water production from oil wells of the Uinta Basin, Uintah and Duchesne Counties, Utah: Utah Geological and Mineralogical Survey Water-Resources Bulletin 1, $31 \mathrm{p}$.

Grenney, W. J., and Kraszewski, A. K., 1980, Flow-duration sediment rating curve analysis for three flow regimes for the White River near Ouray, Utah: Report submitted to BIO/WEST, Inc., by Twelve-Nine, Inc., Logan, Utah, $37 \mathrm{p}$.

Hjelmfelt, A. T., and Cassidy, J. J., 1975, Hydrology for engineers and planners: Ames, Iowa, Iowa University Press, $210 \mathrm{p}$.

${ }^{*}$ Holmes, W. F., 1979, Maps showing generalized structure contours on the tops of the Wasatch and Green River Formations, geologic sections, and contours of thickness of the Green River Formation, southeastern Uinta Basin, Utah and Colorado: U.S. Geological Survey Miscellaneous Investigations Map I-1156, scale 1:125,000.

* 1980, Results of test drilling for ground water in the southeastern Uinta Basin, Utah and Colorado: U.S. Geological Survey Water-Resources Investigations 80-951, $90 \mathrm{p}$.

*Holmes, W. F., and Kimball, B. A., 1983, Ground water in the southeastern Uinta Basin, Utah and Colorado: U.S. Geological Survey Open-File Report 83-271, 137 p. (to be printed as a U.S. Geological Survey Water-Supply Paper).

Hood, J. W., and Fields, F. K., 1978, Water resources of the northern Uinta Basin area, Utah and Colorado, with special emphasis on ground-water supply: Utah Department of Natural Resources Technical Publication 62, 75 p.

Iorns, W. V., Hembree, C. H., Phoenix, D. A., and Oakland, G. L., 1964, Water resources of the Upper Colorado River Basin-Basic data: U.S. Geological Survey Professional Paper 442, 1036 p.

Iorns, W. V., Hembree, C. H., and Oakland, G. L., 1965, Water resources of the Upper Colorado River Basin-Technical report: U.S. Geological Survey Professional Paper 441,370 p.

*Jurado, Antonio, and Fields, F. K., 1978, Channel migration of the White River in the eastern Uinta Basin, Utah and Colorado: U.S.
Geological Survey Miscellaneous Investigations Map I-1087, scale $1: 48,000$.

*Kimball, B. A., 1981, Geochemistry of spring water, southeastern Uinta Basin, Utah and Colorado: U.S. Geological Survey Water-Supply Paper 2074, $30 \mathrm{p}$.

*Lindskov, K. L., and Kimball, B. A., 1982, Quantity and quality of streamflow in the southeastern Uinta Basin, Utah and Colorado: U.S. Geological Survey Open-File Report 82-688, 162 p. (to be printed as U.S. Geological Survey Water-Supply Paper 2224).

Miller, J. F., Frederick, R. H., and Tracey, R. J., 1973, Precipitationfrequency atlas of the Western United States, Volume VI-Utah: National Oceanic and Atmospheric Administration Atlas 2.

Milton, Charles, and Eugster, H. P., 1959, Mineral assemblages of the Green River Formation, in Abelson, P. H., ed., Researches in Geochemistry: New York, John Wiley, p. 118-150.

*Naten, R. W., and Fuller, R. H., 1981, Selected biological characteristics of streams in the southeastern Uinta Basin, Utah and Colorado: U.S. Geological Survey Water-Resources Investigations 81-644, 38 p.

Nowacki, Perry, ed., 1981, Oil shale technical data handbook: Noyes Data Corporation, 309 p.

Price, Don, and Arnow, Ted, 1974, Summary appraisals of the Nation's ground-water resources-Upper Colorado Region: U.S. Geological Survey Professional Paper 813-C, 40 p.

Price, Don, and Miller, L. L., 1975, Hydrologic reconnaissance of the southern Uinta Basin, Utah and Colorado: Utah Department of Natural Resources Technical Publication 49,66 p.

Probstein, R. F., and Gold, H., 1978, Water in synthetic fuel production-The technology and alternatives: MIT Press, $296 \mathrm{p}$.

*Seiler, R. L., and Tooley, J. E., 1982, Erosion and sediment characteristics of the southeastern Uinta Basin, Utah and Colorado: U.S. Geological Survey Water-Resources Investigations 82-428, 44 p.

Stuber, H. A., and Leenheer, J. A., 1978, Assessment of a resin-based fractionation procedure for monitoring organic solutes from oilshale retorting wastes: Symposium on Establishment of WaterQuality Monitoring Programs, Proceedings of American Water Resources Association, San Francisco, June 12-14, 1978, p. 266-272.

Stuber, H. A., Leenheer, J. A., and Farrier, D. S., 1978, Inorganic sulfer species in waste waters from in situ oil-shale processing: Journal of Environmental Science and Health, v. 13, no. 9, p. 663-675.

Thomas, H. E., 1952, Hydrologic reconnaissance of the Green River in Utah and Colorado: U.S. Geological Survey Circular 129, 32 p.

U.S. Bureau of Land Management, 1972, Areas of responsibility and land status map-State of Colorado: Denver, Colorado State Office, U.S. Bureau of Land Management, scale 1:500,000.

1977, Areas of responsibility and land status map-State of Utah: Salt Lake City, Utah State Office, U.S. Bureau of Land Management, scale 1:500,000.

1980, Draft environmental impact statement of the White River Dam project: U.S. Bureau of Land Management, $207 \mathrm{p}$.

U.S. Bureau of Reclamation, 1974: Alternative sources of water for prototype oil shale development, Colorado and Utah: Denver, $114 \mathrm{p}$.

U.S. Department of the Interior, 1973, Final environmental statement for the prototype oil shale leasing program: Washington, D.C., 6 vols.

1979, Synthetic fuels development-Earth-science considerations: Library of Congress catalog-card no. 79-600206, 45 p.

U.S. Geological Survey, 1980-82, Water Resources Data for Utah, water years 1979-81: Salt Lake City, annual releases.

U.S. Water Resources Council, 1981, Synthetic fuels development for the Upper Colorado Region water assessment: Federal Register, v. 46 , no. 128 , Monday, July 6, 1981, p. $35054-35070$. 
Utah Division of Water Resources, 1979, White River Dam Project, Proposed action plan: Utah Department of Natural Resources, $45 \mathrm{p}$.

1980, State of Utah Water-1980: Utah Department of Natural Resources, $47 \mathrm{p}$.

VTN, Colorado, Inc., 1977, Final environmental baseline reportFederal prototype oil-shale leasing program, tracts $\mathrm{Ua}$ and $\mathrm{Ub}$, Utah: Vernal, Utah, White River Shale Project.

*Waltemeyer, S. D., 1982, Selected climatic characteristics of the southeastern Uinta Basin, Utah and Colorado: U.S. Geological Survey Water-Resources Investigations 82-91, 33 p.
Ward, J. C., Margheim, G. A., and Lof, G. O. G., 1971, Water pollution potential of spent oil shale residues: U.S. Environmental Protection Agency Water Pollution Control Research Series 14030 EDB $12 / 71,116 \mathrm{p}$.

Ward, J. C., and Reinecke, S. E., 1972, Water pollution potential of snowfall on spent oil shale residues: U.S. Bureau of Mines OpenFile Report 20-72, 52 p.

Weir, J. E., Jr., 1970, Geohydrology of the area near WOSCO (Western Oil Shale Corporation) exploratory hole number 1, Uintah County, Utah: U.S. Geological Survey open-file report, $27 \mathrm{p}$.

Woolley, R. R., 1930, The Green River and its utilization: U.S. Geological Survey Water-Supply Paper 618, 456 p. 